\title{
Spatial Variation in
}

Total Element Concentration in

Soil Within the Northern

Great Plains Coal Region

and

Regional Soil Chemistry in

the Bighorn and

Wind River Basins,

Wyoming and Montana

GEOLOGICAL SURVEY PROFESSIONAL PAPER 1134-A, B
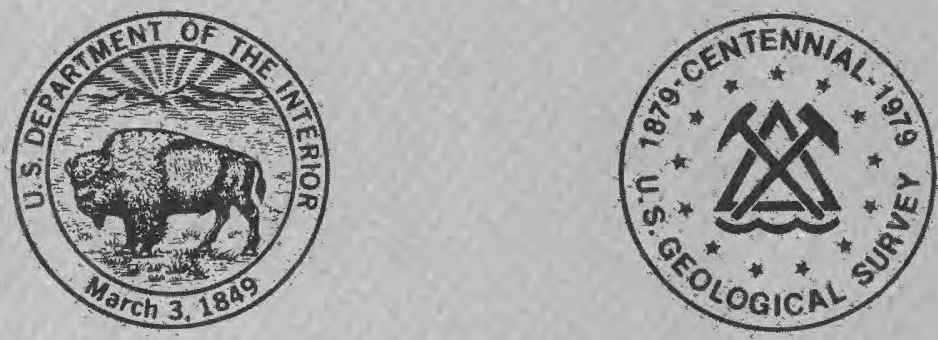



\section{Spatial Variation in Total Element Concentration in Soil Within the Northern Great Plains Coal Region}

By R. C. SEVERSON and R. R. TIDBALL

GEOCHEMICAL SURVEY OF THE WESTERN ENERGY REGIONS

GEOLOGICAL SURVEY PROFESSIONAL PAPER $1134-$ A

Geochemical maps or geochemical baselines

are presented for 40 elements in

$A$ and $C$ horizons of soils

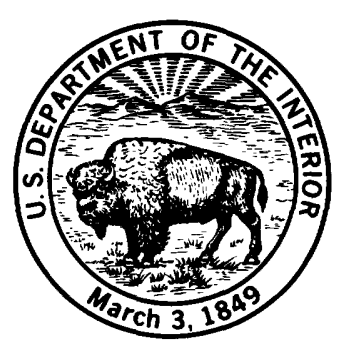




\section{UNITED STATES DEPARTMENT OF THE INTERIOR}

\section{CECIL D. ANDRUS, Secretary}

\section{GEOLOGICAL SURVEY}

H. William Menard, Director

\footnotetext{
Library of Congress Cataloging in Publication Data

Severson, Ronald Charles, 1945-

Spatial Variation in Total Element Concentration in Soil Within the Northern Great Plains Coal Region (Geochemical Survey of the Western Energy Regions) (Geological Survey Professional Paper 1134-A)

Bibliography: p. A17

1. Soil chemistry-Great Plains. 2. Soils-Great Plains-Composition. I. Tidball, Ronald R., joint author.

II. Title. III. Series. IV. Series: United States Geological Survey Professional Paper 1134-A S599.A1S48 631.4'1'0978 79-22136
}

For sale by the Superintendent of Documents, U.S. Government Printing Office

Washington, D. C. 20402

Stock Number 024-001-03230-9 


\section{CONTENTS}

\begin{tabular}{|c|c|c|c|}
\hline \multicolumn{3}{|c|}{ Page } & Page \\
\hline - & & Variance con & 15 \\
\hline (n) & & Variance me & \\
\hline 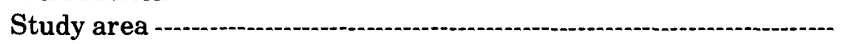 & 1 & Element distribution summaries & \\
\hline le collection, preparation, and analysis & 3 & Differences between soil h & 15 \\
\hline ing design and statistical methods & 3 & Conclusions - & 6 \\
\hline pled population & & References cited & \\
\hline
\end{tabular}

\section{LLUSTRATIONS}

age

A5

17

Page

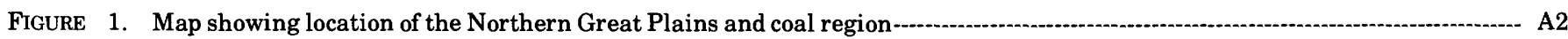

2. Diagram of the unbalanced, nested, analysis-of-variance sampling design

3. Map showing soil-sample localities in the glaciated terrain of the Northern Great Plains coal region ............................. 4

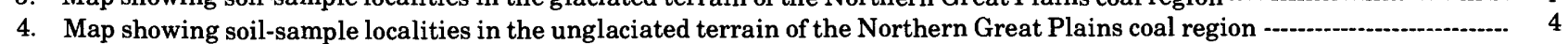

5. Diagram showing frequency distribution of soil parent materials sampled in glaciated and unglaciated terrains of the Northern Great Plains coal region

6. Maps showing regional distribution of elements in $\mathrm{A}$ and $\mathrm{C}$ horizons of soils of the Northern Great Plains coal region:

6A. Arsenic $\mathrm{C}$ horizon

Calcium, Chorizon -.....

6C. Carbon, A horizon -

6D. Carbon, $\mathrm{C}$ horizon

6E. Germanium, $\mathrm{C}$ horizon-1.-1

6F. Potassium, A horizon -....

6G. Potassium, C horizon -

6H. Magnesium, C horizon -

$6 I$. Sodium, A horizon

$6 J$. Rubidium, A horizon -

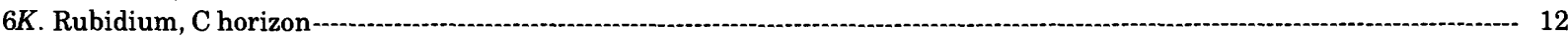

$6 L$. Silicon, A horizon -

$6 M$. Thorium, A horizon-

$6 N$. Uranium, A horizon -

6O. Zinc, A horizon -

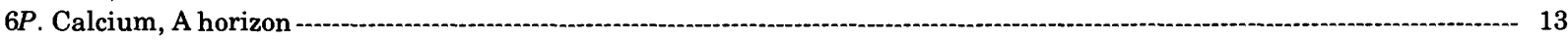

$6 Q$. Iron, A horizon-

6R. Germanium, A horizon-

6S. Molybdenum, A horizon-14

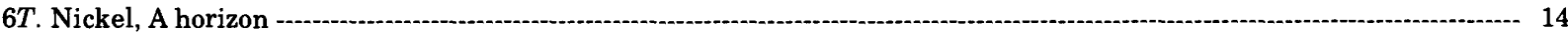

7. Diagram showing discriminate function analysis between A- and C-horizon samples from the Northern Great

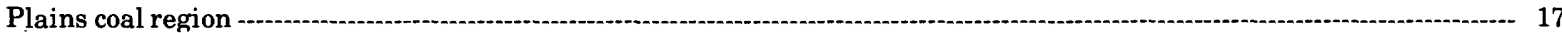

\section{TABLES}

TABLE 1. Variance components and variance mean ratio for two soil horizons from the Northern Great plains coal region -.......-..- A6

2. Unbalanced, nested, analysis-of-variance design used in the Northern Great Plains coal region -............................... 7

3. Grouping of elements based on significant variance components, variance mean ratios, and analytical error variance ---.- 9

4. Chemical summaries for elements in soil that exhibit a significant variance component between terrains of the

Northern Great Plains coal region

5. Chemical summaries for elements in soil that exhibit a non-significant variance component between terrains of the Northern Great Plains coal region 



\title{
SPATIAL VARIATION IN TOTAL ELEMENT CONGENTRATION IN SOIL WITHIN THE NORTHERN GREAT PLAINS COAL REGION
}

\author{
By R. C. Severson and R. R. Tidball
}

\begin{abstract}
To objectively determine the changes in chemical character of an area subjected to mining and reclamation, prior information is needed. This study represents a broadscale inventory of total chemical composition of the surficial materials of the Northern Great Plains coal region (western North and South Dakota, eastern Montana, and northeastern Wyoming); data are given for 41 elements in $\mathrm{A}$ and $\mathrm{C}$ soil horizons.

An unbalanced, nested, analysis-of-variance design was used to quantify variation in total content of elements between glaciated and unglaciated terrains, for four increasingly smaller geographic scales, and to quantify variation due to sample preparation and analysis. From this statistical study, reliable maps on a regional basis $(>100$ $\mathrm{km}$ ) were prepared for $\mathrm{C}, \mathrm{K}$, and $\mathrm{Rb}$ in $\mathrm{A}$ and $\mathrm{C}$ soil horizons; for $\mathrm{Na}, \mathrm{Si}$, $\mathrm{Th}, \mathrm{U}$, and $\mathrm{Zn}$ in A-horizon soil; and for $\mathrm{As}, \mathrm{Ca}, \mathrm{Ge}$, and $\mathrm{Mg}$ in C-horizon soil. The distribution of variance components for the remaining 29 elements did not permit the construction of reliable maps. Therefore, a baseline value for each of these elements is given as a measure of the total element concentration in the soils of the Northern Great Plains coal region. The baseline is expressed as the 95-percent range in concentration to be expected in samples of natural soils.
\end{abstract}

\section{INTRODUCTION}

The present and future role of the Northern Great Plains in supplying coal and other minerals to meet energy requirements dictates the need for timely information on the chemical character of the soils that will be disturbed by mining and reclamation. In order to evaluate the chemical character of soil, or any other natural material, its variability needs to be quantified so that inferences having known degree of certainty can be made from the data that are collected.

Most previous studies to determine variability in soil constituents have been related to agronomic or taxonomic problems (Beckett, 1967; Beckett and Webster, 1971; Crosson and Protz, 1974; Drees and Wilding, 1973; Jansen and Arnold, 1976; McCormack and Wilding, 1969; McKenzie, 1955; Oertel, 1959; Protz, Presant, and Arnold, 1968; Reynolds, 1975; Walker, Hall, and Protz, 1968; Webster and Butler, 1976; and Wilding, Jones, and Schafer, 1965). These studies considered dif- ferent soil properties at different geographic scales from those considered in this study. Therefore, their conclusions could not be applied directly at the planning stages of, or to the results of, the present investigation. However, their results indicate, in general, that soil properties tend to exhibit a large local variability within the context of the many different sampling designs.

Studies by Connor, Keith, and Anderson (1976); Erdman, Shacklette, and Keith (1976); Tidball (1976); Tidball and Ebens (1976); and Tourtelot and Miesch (1975) addressed variability of total element concentration in soil on the basis of large mapping-units. Information from these studies was used in planning the present study. In general, these studies also indicated that variability at local scales is large.

The objectives of the present study were three-fold: (1) To provide background information on element concentrations in soil of the Northern Great Plains coal region before mining and reclamation. (2) To evaluate the magnitude of the variability in element concentration in soil at different geographic scales. Knowing the variability, inferences can be made about the soils with a known degree of confidence, and the sample load that would be needed to make inferences at a specified level of certainty can be determined. (3) Either to prepare reliable maps of element concentrations in soil on a regional basis, or to determine the number of samples that would be required to prepare reliable maps for those elements for which adequate data are not available.

\section{STUDY AREA}

The study area consists of the part of the Northern Great Plains (fig. 1) whose surface is underlain by geologic formations that contain large resources of 
strippable coal. This area is underlain mainly by finegrained, nonmarine sediments in the Wasatch and Fort Union Formations of early Tertiary age (Keefer, 1974). The boundaries of this area are modified from a U.S. Geological Survey map (1974) for the part within the United States, and from Whitaker and Pearson (1972) for the part in Canada (fig. 1).

Within this area, the greatest contrast in surface features and soil-parent materials is between glaciated and unglaciated areas. Glacial drift generally occupies the area to the north and east of the Missouri River (fig. 1). The glaciated area is an undulating plain having local relief of less than $10 \mathrm{~m}$; closed depressions are common and a well-developed stream drainage is lacking. Nearly level areas of glacial outwash and locallyoccurring glacial lake deposits are widespread throughout the glaciated areas. Compared to the drift plain, areas of moraines have steeper slopes, deeper depressions, and a veneer of gravel and boulders; glacial moraines rise above the subdued topography of the drift plain, with local relief of 15 to $30 \mathrm{~m}$. Eolian sediments that are generally found east of and adjacent to major drainages blanket the glacial drift and tend to smooth the undulating surface. Some small areas that were not

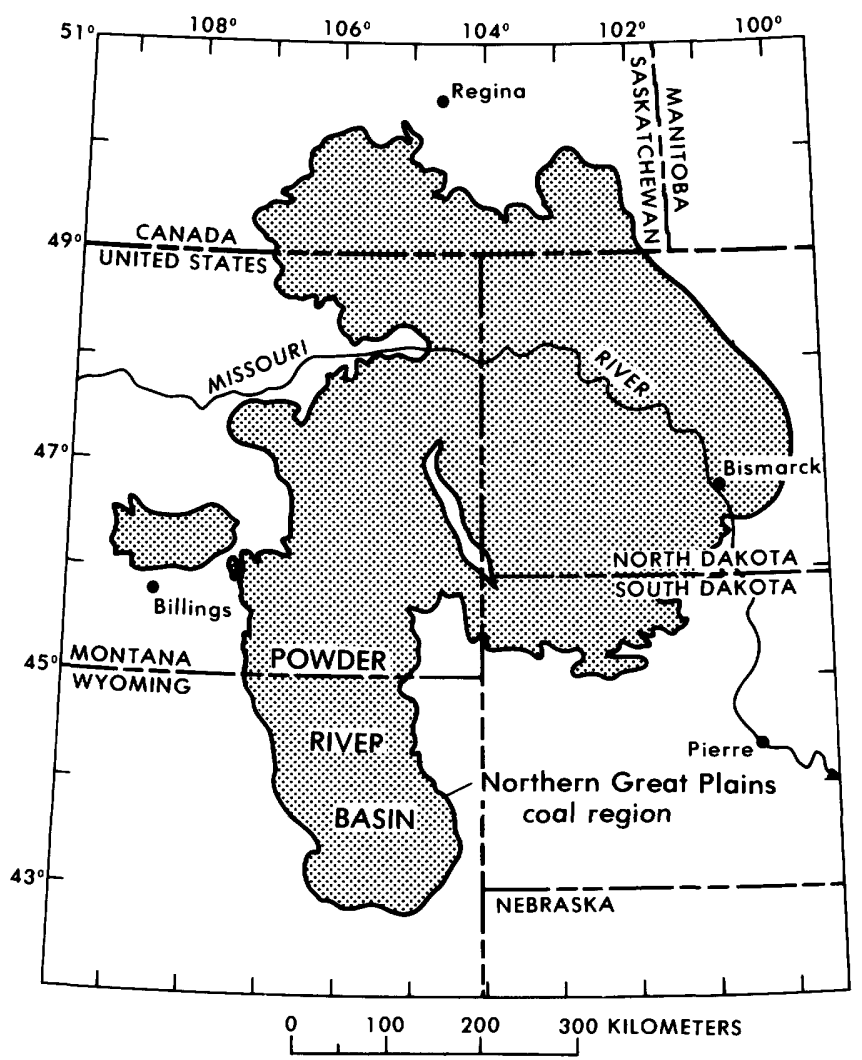

FIGURE 1.-Location of the Northern Great Plains coal region; area containing coal deposits of Tertiary age indicated by stipple pattern. covered by glacial drift or from which the glacial drift has been removed by erosion are interspersed throughout the drift plain.

The transitional area between the glaciated and unglaciated landscapes is generally delineated by the Missouri River Valley. This area has erosion extending as much as $180 \mathrm{~m}$ into the soft sediments of the adjacent uplands. The valley is generally less than $3 \mathrm{~km}$ wide, and severely dissected canyons impinge upon the surrounding uplands. The valley contains thick deposits of recent alluvium flanked by older terrace deposits.

On the unglaciated plain to the south and west of the Missouri River a parallel drainage pattern has formed, and some stream valleys are as much as $60 \mathrm{~m}$ deep. The upland is a gently rolling plain with isolated to closely spaced buttes as much as $200 \mathrm{~m}$ higher than the adjacent surface. In some localities, mountain outliers are flanked with pediments and merge with alluvial fans and terraces in the adjacent upland. Between the mountain outliers broad anticlines and synclines control the topographic character of the unglaciated plain. Where thick units of shale are near the surface, they are highly dissected to form "badlands." Spontaneous combustion of some lignite beds in the Tertiary formations has baked the overlying sediments to form reddish colored clinker beds, which are a distinctive feature of the unglaciated area.

The paleogeography of the sediments of Late Cretaceous age in the Northern Great Plains is outlined by Gill and Cobban (1973). Paleogeography of deposits of Tertiary and Pleistocene ages for northeastern Montana and northwestern North Dakota is detailed by Howard (1960). Mineralogy of the major stratigraphic units of Tertiary age in the Northern Great Plains is presented by Denson and Chisholm (1971).

A general description of soil-development gradients by Hunt (1967, p.85-93) indicated that temperature and moisture interactions, as they influence the depth of water penetration in soil, are the major factors that determine the degree of soil development in the Northern Great Plains. Soil moisture and soil temperature were also the major criteria used by Aandahl (1972) to map major taxonomic soil classes in the Great Plains region. The climate of the Northern Great Plains is cool-temperate-subhumid to semiarid, and is not conducive to intense soil development. Depth of solum, horizonation, and accumulation of salts are properties that indicate the intensity of soil development in the Northern Great Plains. Soil development and soil pedons are described by Dunnewald (1957) for Wyoming, by Omodt and others (1968) for North Dakota, by Southard (1969) for Montana, and by Westin, Puhr, and Buntley (1967) for South Dakota. 


\section{SAMPLE COLLECTION, PREPARATION, AND ANALYSIS}

Samples of A- and C-horizons of soils were collected in the Northern Great Plains coal region (fig. 1) in the fall of 1974. An A-horizon sample consisted of a channel composite of the top $10 \mathrm{~cm}$. A C-horizon sample consisted of a channel composite at a depth of from 100 to 120 $\mathrm{cm}$; if consolidated rock was encountered before this depth was reached, the sample consisted of the $10 \mathrm{~cm}$ of material immediately above the rock zone. All samples were collected using a barrel auger that was $10 \mathrm{~cm}$ in diameter.

The samples were dried at ambient temperature under forced air and then were disaggregated in a motor-driven ceramic mortar-and-pestle to pass a 2-mm stainless steel sieve. These samples were further ground to minus-100 mesh (minus $149 \mu \mathrm{m}$ ) in a ceramic mill, and splits of this material were used for all chemical determinations.

All analyses were done in the laboratories of the U.S. Geological Survey at Denver, Colorado. Analyses were performed by James W. Baker, Leon A. Bradley, Isabelle Davidson, Andrew Drenick, Jefferey England, Johnnie M. Gardner, Patrica Gayle Guest, Raymond G. Havens, Claude Huffman, Jr., J. O. Johnson, Lorraine Lee, R. M. Lemert, R. E. McGregor, H. T. Millard, Jr., Wayne Mountjoy, Farris D. Perez, Van E. Shaw, George D. Shipley, Arthur L. Sutton, Jr., James A. Thomas, Michele L. Tuttle, Richard E. Van Loenen, James S. Wahlberg, and Thomas L. Yager. The analytical methods employed are described in U.S. Geological Survey (1975) by James S.
Wahlberg (p. 69), Claude Huffman, Jr. (p. 71), H. T. Millard, Jr. (p. 79), and in U.S. Geological Survey (1976) by Arthur L. Sutton, Jr. (p. 131).

\section{SAMPLING DESIGN AND STATISTICAL METHODS}

The pattern adopted for collecting soil samples for this study (fig. 2) is a six-level, unbalanced, nested, analysis-of-variance design (Leone and others, 1968). The highest level compares variation in element composition of soil from glaciated terrain with soil from unglaciated terrain. Within the irregular boundaries of each terrain, cells $100 \mathrm{~km}$ on a side were arranged to include as much of each terrain as possible (figs. 3 and 4). This arrangement resulted in $12100-\mathrm{km}$ cells within the glaciated terrain and $22100-\mathrm{km}$ cells within the unglaciated terrain.

Each of the $100-\mathrm{km}$ cells was partitioned into areas of decreasing size, as follows: four $50-\mathrm{km}$ cells, each of which was divided into $2510-\mathrm{km}$ cells, which were then divided into $1001-\mathrm{km}$ cells. Cells to be sampled were randomly selected, as follows: two $50-\mathrm{km}$ cells, two $10-\mathrm{km}$ cells in one $50-\mathrm{km}$ cell and one $10-\mathrm{km}$ cell in the other $50-\mathrm{km}$ cell, two $1-\mathrm{km}$ cells in one $10-\mathrm{km}$ cell and one $1-\mathrm{km}$ cell in each of the two other $10-\mathrm{km}$ cells. This resulted in samples of $\mathrm{A}$ and $\mathrm{C}$ horizons from each of 136 locations -48 in the glaciated terrain and 88 in the unglaciated terrain.

An estimate of variance due to all laboratory procedures (analytical error) was made from data on 28 randomly selected samples (out of a total of 272)-12 A-horizon samples and $16 \mathrm{C}$-horizon samples - that were

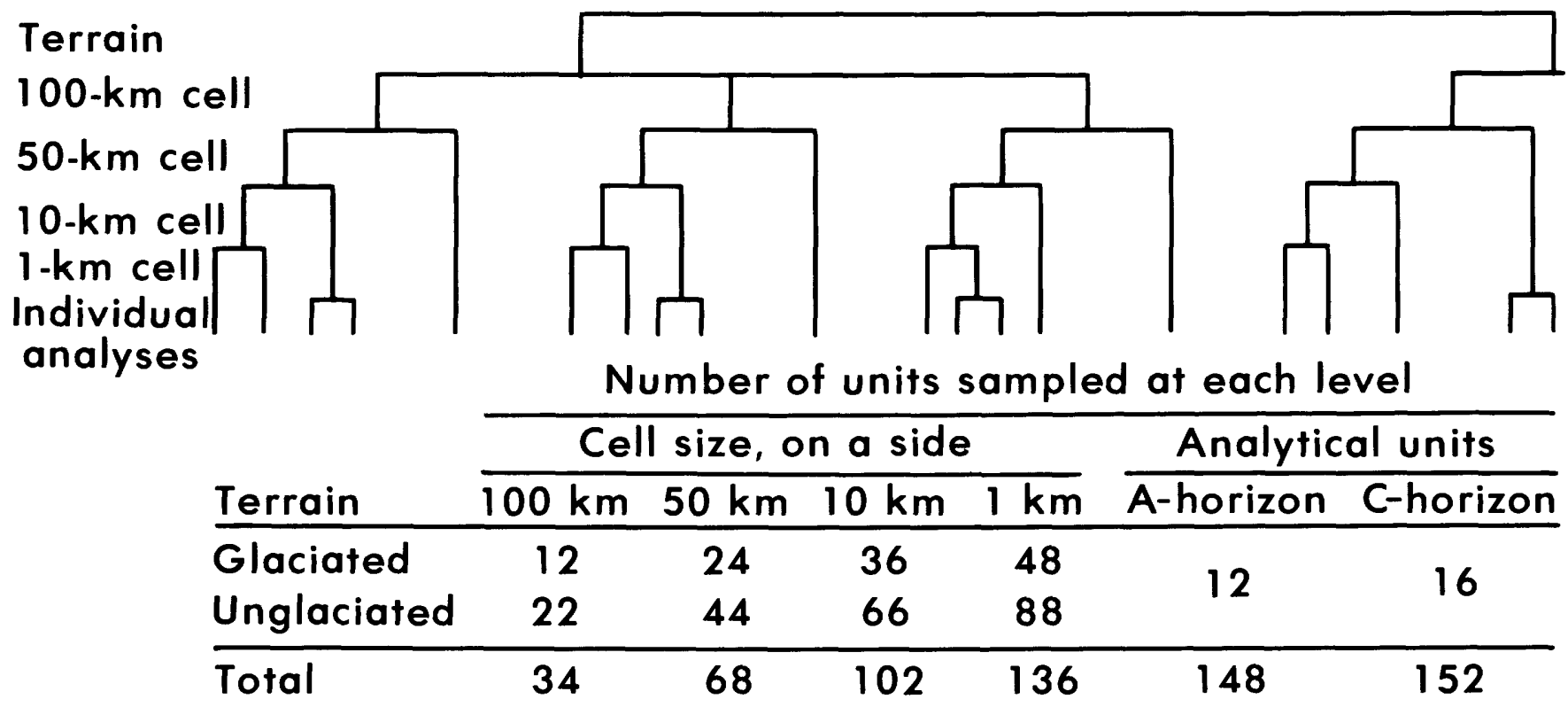

FIGURE 2.-Diagram of the unbalanced, nested, analysis-of-variance sampling design. 


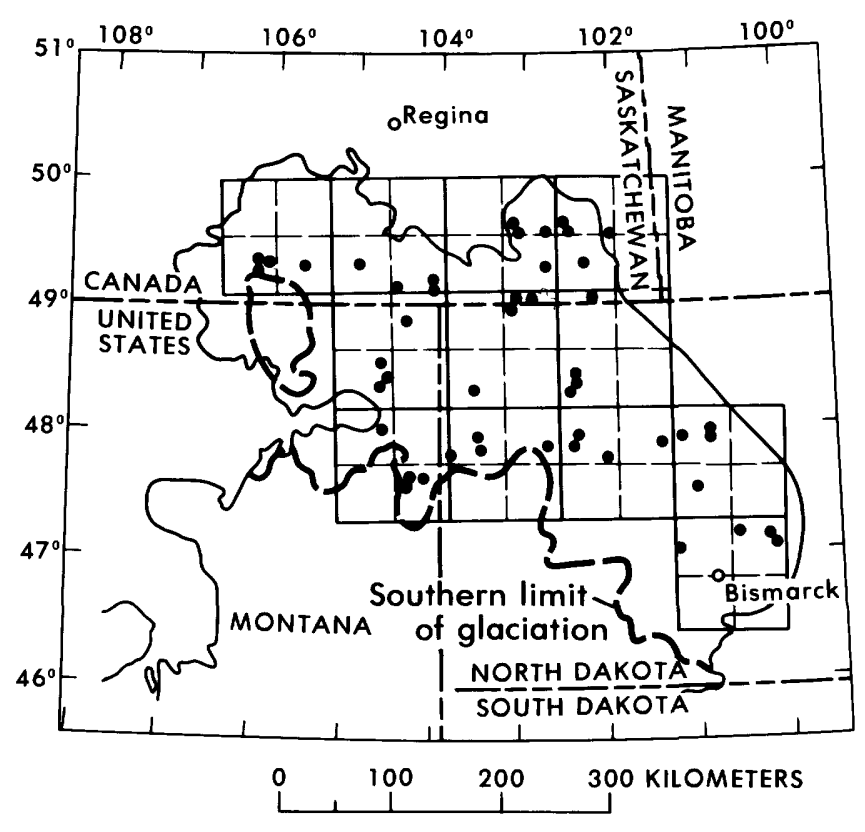

FIGURE 3.-Soil-sample localities in the glaciated terrain of the Northern Great Plains coal region. Large squares (solid lines) are $100 \mathrm{~km}$ on a side; smaller squares (dashed lines) are $50 \mathrm{~km}$ on a side. Dots are sampling sites. The limit of glaciation is modified from Colton, Lemke, and Lindvall (1963) for North Dakota and from Colton, Lemke, and Lindvall (1961) for Montana.

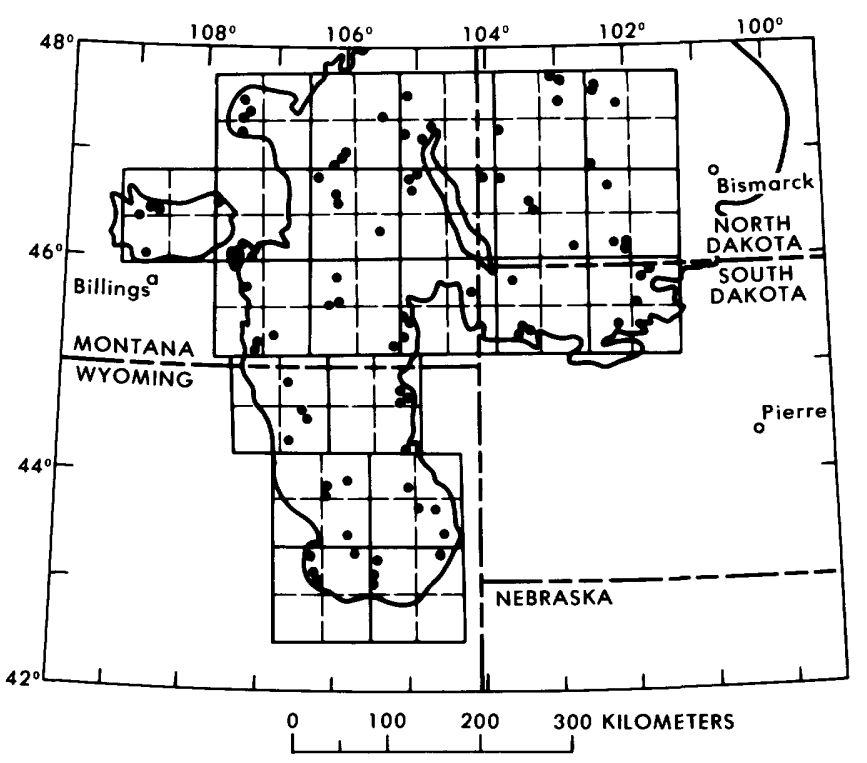

FIGURE 4.-Soil-sample localities in the unglaciated terrain of the Northern Great Plains coal region. Large squares (solid lines) are $100 \mathrm{~km}$ on a side; smaller squares (dashed lines) are $50 \mathrm{~km}$ on a side. Dots are sampling sites. Modified from U.S. Geological Survey (1974). The limit of glaciation is modified from Colton and others (1963) for North Dakota and from Colton and others (1961) for Montana. split and analyzed twice. These duplicate samples were randomly interspersed among the original samples, and the entire suite of 300 samples was analyzed in a randomized sequence; thus, any systematic analytical error would be transformed into a random error.

The components of variance estimated by the sampling design are as follows: the level 1 (terrains) component is $\alpha^{2}$; the level 2 (100-km cells) component is $\alpha_{\beta}{ }^{2}$; the level 3 (50-km cells) component is $s_{\gamma}{ }^{2}$; the level 4 (10-km cells) component is $s \delta^{2}$; the level 5 (1-km cells) component is $s \eta^{2}$; and the level 6 (analytical error) component is $s_{\epsilon}{ }^{2}$.

The statistical model is represented by the following equation:

$x_{\imath j k l m n}=\mu+\alpha_{i}+\beta_{i, j}+\gamma_{i j k}+\delta_{i j k l}+\eta_{i j k / m}+\epsilon_{i j k / m n}$

where $x_{i j k l m n}$ is a measure of element concentration in a single sample (the $n$th analysis, of the $m$ th sample, of the $l$ th $1-\mathrm{km}$ cell, and so forth): $\mu$ is the mean for the population sampled; and $\alpha, \beta, \psi, \delta, \eta$, and $\epsilon$ are deviations from the mean associated, respectively, with terrains, distances of $100,50,10$, and $1 \mathrm{~km}$, and random errors related to sample preparation and analysis. The variance components, as estimated by the analysis-of-variance computation methods following Anderson and Bancroft (1952), are expressed as follows:

$$
s_{, x}{ }^{2}=s_{\alpha}{ }^{2}+s_{\beta}{ }^{2}+s_{\gamma}{ }^{2}+s_{\delta}^{2}+s_{\eta}{ }^{2}+s_{\epsilon}{ }^{2}
$$

where $s x^{2}$ is an estimate of the total observed variation for an element in soil, and the remaining terms are the variance components described above. All computations were done on a computer using statistical programs in the U.S. Geological Survey's STATPAC Library (Van Trump and Miesch, 1977).

The unbalanced design was chosen in preference to a balanced design, because it has the advantage of spreading the degrees of freedom almost equally over levels 2-6. Also, the number of degrees of freedom achieved in the higher levels of the unbalanced design is comparable to that achieved in the balanced design, but with only one-half the number of samples. Therefore, the power of the F-test at the higher levels of the unbalanced design is equivalent to that for a balanced design, and yet the cost for sample collection and analyses is only about one-half as much.

Concentrations of some elements are below the limit of determination by a given analytical method, so they are omitted, or "censored." When more than 20 percent of the determinations for an element are below the limit of detection, the element is omitted from further consideration. Elements omitted include $\mathrm{Ag}, \mathrm{Au}, \mathrm{Bi}, \mathrm{Br}, \mathrm{Cd}, \mathrm{Ce}, \mathrm{Cl}$, Cs, Dy, Er, Gd, Hf, Ho, I, In, Ir, La, Nd, Os, Pd, Pr, Pt, Re, $\mathrm{Rh}, \mathrm{Ru}, \mathrm{S}, \mathrm{Sm}, \mathrm{Ta}, \mathrm{Tb}, \mathrm{Te}, \mathrm{Tl}, \mathrm{Tm}$, and W. For elements with less than 20 percent censored values, the censored 
values were replaced by small, arbitrary values. These replacement values can be justified because their small number neither alters the statistical tests nor affects the final interpretation of the data.

The data for all elements except $\mathrm{Na}, \mathrm{Si}$, Th, and $\mathrm{Zn}$ were transformed by taking the common logarithm, because frequency distributions of the data were more nearly log-normal than normal. All data are reported in terms of either logarithmic (transformed data) or arithmetic variance, means, and deviations. Unless a statistical term is prefixed by "arithmetic," the term refers to logarithmically transformed data.

\section{SAMPLED POPULATION}

The population sampled in this study is in the Northern Great Plains coal region and consists of all soils developed either from glaciated materials or from rocks in the Fort Union and Wasatch Formations of early Tertiary age. The 136 sample localities that represent the population were randomly selected within the several nested cells. The diversity of sedimentary parent materials for the soils sampled is shown in figure 5 . If indeed the random sampling procedure was unbiased and if the number of samples was sufficiently large, then figure 5 would also show the proportional distribution of parent materials for soils in the Northern Great Plains coal region.

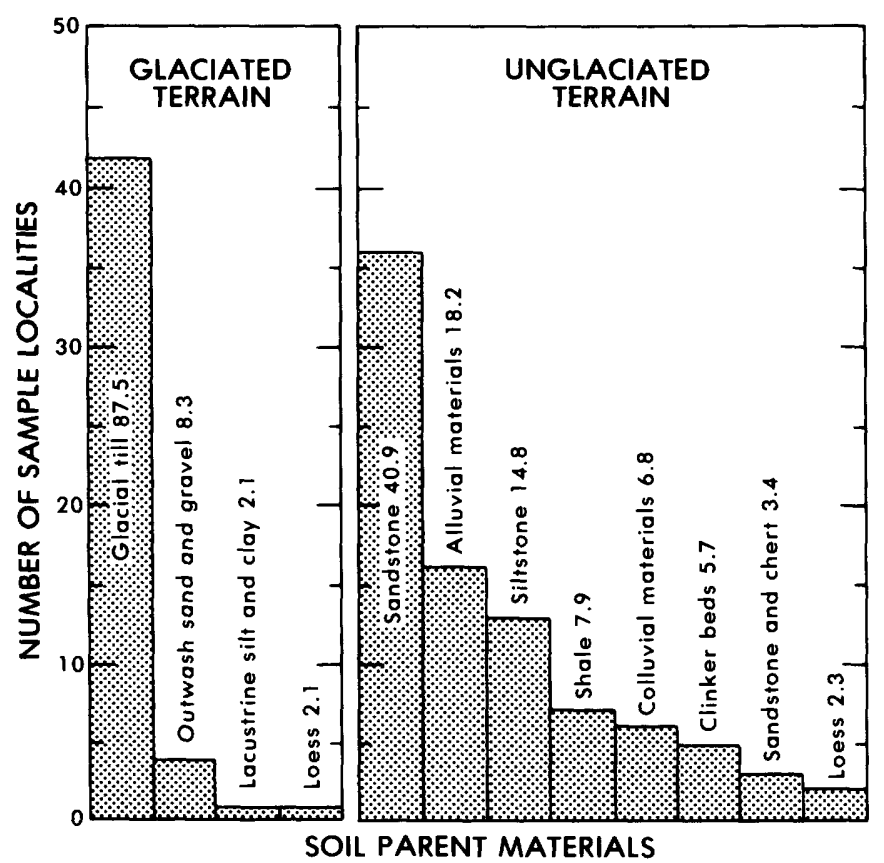

Figure 5.-Frequency distribution, in percent, of soil parent materials sampled in glaciated and unglaciated terrains of the Northern Great Plains coal region.
As suggested by figure 5, a natural division exists between glaciated and unglaciated terrains in terms of the character of the parent materials. The division is significant for two reasons: (1) The total chemical character of the soils of the different terrains should be distinct because of the different amounts of time over which pedologic processes have been acting. (2) The mineralogy, source areas, and mode of deposition of parent materials of glacial origin are distinctly different from those of the Tertiary sediments. These differences should be reflected in the chemical variation between the soils of the two terrains. The highest level of the sampling design is, therefore, intended to estimate differences in chemical variation between the two terrains. Before discussing terrain differences, however, it will be helpful to discuss variance components.

\section{VARIANCE COMPONENTS}

Within each terrain, sampling was designed to measure variation over increments of distance expressed in terms of cell size. Thus, the total variance was subdivided into components, each associated with a given cell size. The distribution of variance components for 41 elements in both $\mathrm{A}$ and $\mathrm{C}$ horizons (82 combinations), each expressed as a percentage of the total variance, is shown in table 1.

Of the 82 entries in table 1, 21 exhibit an analyticalerror-variance component that is greater than 50 percent of the total observed variance. This amount is excessive and these elements are excluded from further interpretation. Reduction of the analytical-errorvariance component to an acceptable level requires a more precise analytical method or repeated analyses of the sample. Generally, as analytical precision or number of analyses is increased, the cost rises. It is necessary, therefore, to balance the value of the results against the increased cost of more precise or repeated analyses for each element.

The variance distribution indicates that, for most elements, the largest variance occurs at a local level; that is, within areas $10 \mathrm{~km}$ or less on a side. In fact, it is not uncommon for most of the variance to occur within distances of $1 \mathrm{~km}$. This could logically be expected where a variety of different sample materials are found in a small area (for example, outwash gravel and lacustrine silt and clay in glacial terrain, or sandstone and shale in unglaciated terrain). Naturally, the variance in element distribution between soils developed from diverse materials would be greater than variances between soils from the same type of material. Independent studies by Tidball (1975), Tidball and Ebens (1976), and Keith, Anderson, and Connor (1974) of soil in the Powder River 
TABLE 1.-Variance components (expressed as percent of total variance) for 41 elements in $A$ and $C$ horizons of soils from the Northern Great Plains coal region, and the variance mean ratio for $100-k m$ cells. An asterisk indicates significance at the 0.05 probability level

\begin{tabular}{|c|c|c|c|c|c|c|c|c|c|}
\hline Element & $\begin{array}{c}\text { Soil } \\
\text { horizon }\end{array}$ & $\begin{array}{c}\text { Total log } \\
\text { variance }\end{array}$ & $\begin{array}{l}\text { Between } \\
\text { terrains }\end{array}$ & $\begin{array}{c}\text { Between } \\
100-\mathrm{km} \text { cells }\end{array}$ & $\begin{array}{c}\text { Between } \\
50-\mathrm{km} \text { cells }\end{array}$ & $\begin{array}{c}\text { Between } \\
10-\mathrm{km} \text { cel1s }\end{array}$ & $\begin{array}{c}\text { Between } \\
1-\mathrm{km} \text { cells }\end{array}$ & $\begin{array}{l}\text { Analytical } \\
\text { error }\end{array}$ & $v_{m}^{1}$ \\
\hline \multirow[t]{2}{*}{ A1----- } & A & 0.0069 & $11.7 *$ & 0 & $32.3 *$ & 3.3 & $31.7 \star$ & 21.0 & 0.34 \\
\hline & c & .0106 & $11.0 *$ & 0 & 16.2 & 0 & $66.9 *$ & 5.9 & .39 \\
\hline \multirow[t]{2}{*}{ As:-_--- } & A & 1338 & 0 & 11.9 & 0 & 0 & $83.7 *$ & 4.4 & .52 \\
\hline & c & .1290 & 0 & $31.8^{*}$ & 0 & 7.4 & $56.8 *$ & 4.0 & 1.68 \\
\hline \multirow[t]{2}{*}{ B-D-C- } & A & .0446 & 0 & 8.8 & 0 & $48.9 *$ & 18.4 & 23.9 & .30 \\
\hline & & .0466 & .7 & 10.2 & 0 & 12.1 & $69.7 *$ & 7.3 & .46 \\
\hline Ba--..- & A & .0175 & 0 & 6.3 & 0 & 3.1 & 3.2 & 87.5 & .26 \\
\hline & c & .0629 & 0 & $9.0^{*}$ & 0 & $21.9 *$ & 0 & 69.1 & .35 \\
\hline Be--W- & A & .0340 & $6.4 \pi$ & .03 & 6.4 & 0 & $55.7^{*}$ & 31.4 & .25 \\
\hline & c & .0477 & 1.3 & 0 & $52.1 *$ & 0 & $28.9 *$ & 17.6 & .03 \\
\hline c-----. & A & .0444 & $25.6 *$ & $20.7^{*}$ & 0 & 4.7 & $48.5 *$ & .5 & 3.3 \\
\hline & c & .1293 & $21.2 \star$ & $12.5 *$ & 0 & 13.6 & $52.1 *$ & .6 & 1.8 \\
\hline $\mathrm{Ca}+\cdots-$ & A & .1586 & 0 & $18.8 *$ & 0 & 21.3 & $59.5 *$ & .4 & .82 \\
\hline & c & .1166 & $26.4 *$ & 4.0 & 4.6 & 7.2 & $57.4 *$ & .4 & 1.5 \\
\hline Co-C-O- & A & .0400 & 0 & 0 & $49.0 *$ & 3.5 & 25.0 & 22.5 & 0 \\
\hline & c & .0411 & .6 & 0 & 24.9 & 0 & $58.5 *$ & 16.0 & .02 \\
\hline$C_{r}-\cdots-$ & A & .0434 & $0^{\circ}$ & $17.2 *$ & 0 & 0 & 15.3 & 67.5 & .83 \\
\hline & C & .0679 & .7 & 0 & $32.2 *$ & 0 & $42.0^{*}$ & 25.1 & .02 \\
\hline Cu--.-- & A & .0470 & .7 & 0 & 22.7 & 2.8 & $44.5 *$ & 29.4 & .02 \\
\hline & c & .0877 & 0 & 0 & 17.8 & 0 & $48.2 *$ & 34.0 & 0 \\
\hline F------ & A & .0827 & $2.4 *$ & $11.8 *$ & 5.4 & 0 & 0 & 80.4 & .60 \\
\hline & c & .0693 & .1 & 0 & 0 & $26.2 \star$ & 0 & 73.7 & $<0.01$ \\
\hline Fe----- & A & .0329 & 0 & $18.1 *$ & & $62.9 *$ & $18.6 *$ & .4 & .64 \\
\hline & c & .0291 & 0 & 0 & $20.2 *$ & 0 & $79.5 *$ & .3 & 0 \\
\hline Ga--D.- & A & .0287 & 3.0 & 0 & 10.4 & 0 & 42.5 & 44.0 & .11 \\
\hline Ge-----. & $\begin{array}{l}\text { C } \\
\text { A }\end{array}$ & .0565 & $2,0 \star$ & 0 & $29.2 \star$ & 0 & $41.3 *$ & 27.6 & .06 \\
\hline & c & $\begin{array}{l}.1546 \\
.0746\end{array}$ & $\begin{array}{l}0 \\
0\end{array}$ & $\begin{array}{l}14.4 * \\
29.2 *\end{array}$ & $\begin{array}{l}0 \\
0\end{array}$ & $\begin{array}{c}29.4 \\
0\end{array}$ & $\begin{array}{l}54.5 * \\
65.5 *\end{array}$ & $\begin{array}{l}1.7 \\
5.3\end{array}$ & $\begin{array}{r}.55 \\
1.58\end{array}$ \\
\hline $\mathrm{Hg}_{\mathrm{H}-\cdots-}$ & A & .0672 & $6.4 \pi$ & 4.8 & 0 & $55.0 *$ & 2.9 & 30.9 & .39 \\
\hline & c & .0736 & 3.8 & 3.7 & 6.3 & 0 & 82.9 & 3.3 & .29 \\
\hline k----- & A & .0038 & $43.7 *$ & 0 & 13.3 & 4.4 & $36.6 *$ & 2.0 & 2.2 \\
\hline & $\ddot{c}$ & .0083 & $39.6 *$ & 0 & $21.6 *$ & 2.4 & $35.9 *$ & .5 & 1.7 \\
\hline La---- & A & .0353 & 2.7 & 0 & 0 & 9.4 & 30.3 & 57.5 & .11 \\
\hline a & $\mathrm{c}$ & .0508 & .4 & 0 & 15.9 & 0 & $45.3 *$ & 38.4 & .01 \\
\hline Li-C. & A & .0209 & 3.0 & 4.1 & 11.1 & .1 & 79.1 & 2.6 & .26 \\
\hline & $\mathrm{c}$ & .0440 & 0 & 0 & 25.4 & 0 & $68.2 *$ & 6.4 & 0 \\
\hline Mg----- & A & .0477 & 0 & 5.2 & 40.3 & 18.8 & $35.5 *$ & .2 & .13 \\
\hline & c & .0620 & $10.7 *$ & $17.2 \star$ & 0 & $27.6 *$ & $44.4 *$ & .1 & 1.3 \\
\hline Mn---.- & A & .1851 & $22.6 *$ & 0 & 0 & $33.0 *$ & 8.2 & 36.2 & .96 \\
\hline & $\mathrm{c}$ & .2361 & $10.6 *$ & 0 & $34.1 *$ & 4.2 & 24.3 & 26.8 & .30 \\
\hline Mo----- & A & .1068 & 0.5 & $7.8 *$ & 11.1 & 0 & 44.4 & 36.2 & .31 \\
\hline & c & .1860 & 0 & 0 & $32.5 *$ & 0 & 25.7 & 41.8 & 0 \\
\hline $\mathrm{Na}---$ & A & .0774 & 7.7 & $19.5 *$ & 10.1 & 0 & $62.2 \star$ & .5 & 1.2 \\
\hline & $\mathrm{c}$ & .1249 & 1.6 & 7.2 & 0 & 29.2 & $61.1 *$ & .9 & .33 \\
\hline Nb----- & A & .0510 & .7 & 0 & $19.1 *$ & 0 & 24.5 & 55.7 & .02 \\
\hline & C & .0600 & 0 & 0 & 21.3 & 18.8 & 0 & 59.9 & 0 \\
\hline Ni----- & $\mathbf{A}$ & .0275 & 0 & $11.0 *$ & 0 & 12.3 & 40.6 & 36.0 & .46 \\
\hline & $\mathrm{c}$ & .0519 & $3.8 \star$ & 0 & 20.8 & 0 & $58.2 *$ & 17.2 & .12 \\
\hline P------ & A & .0319 & 0 & 1.1 & 5.7 & 0 & 0 & 93.2 & .04 \\
\hline & $\mathrm{c}$ & .0281 & 0 & 0 & 17.9 & 0 & 4.9 & 77.2 & $0^{.04}$ \\
\hline Pb--.-- & A & .0396 & 1.9 & 0 & 9.9 & 0 & 26.6 & 61.6 & .07 \\
\hline & C & .0826 & 1 & 0 & $39.6 *$ & 0 & $35.4 *$ & 24.9 & $<0.01$ \\
\hline Rb----- & A & .0093 & $25.0 *$ & $11.1 *$ & 0 & $29.2 \star$ & $24.8 *$ & 9.9 & 1.8 \\
\hline & c & .0186 & $31.2 \star$ & 0 & 3.3 & 9.4 & $49.3 *$ & 6.8 & 1.6 \\
\hline Sb----- & A & .4064 & 0 & 0 & 0 & 14.8 & 0 & 85.2 & 0 \\
\hline & c & .4376 & .8 & 0 & 3.1 & 0 & 39.2 & 56.9 & .03 \\
\hline Sc----- & A & .0622 & 0 & 9.1 & 0 & 6.9 & 21.3 & 62.2 & .39 \\
\hline & c & .0772 & 2.2 & 0 & 22.9 & 0 & 5.8 & 69.1 & .07 \\
\hline Se------ & A & .3418 & $3.2 \star$ & 0 & 1.9 & 0 & $61.5 *$ & 33.4 & .07 \\
\hline & c & .2549 & 2.1 & 0 & 6.6 & 0 & 76 & 83.7 & .08 \\
\hline $\mathbf{S i}^{2}$ & $\mathbf{A}$ & 9.531 & 0 & $27.0 *$ & 0 & 7.6 & $52.0 *$ & 13.4 & 1.4 \\
\hline & $c$ & 12.61 & $6.9 *$ & 9.3 & 0 & 7.3 & $64.7 \star$ & 11.8 & .74 \\
\hline Sn- ---- & A & .1690 & .9 & 2.3 & 0 & $43.4^{\star}$ & $34.5 *$ & 18.8 & .10 \\
\hline & $c$ & .1662 & 5.1 & 8.3 & 0 & 0 & $71.5 *$ & 15.1 & .60 \\
\hline str---.- & A & 0295 & $8.8^{\star}$ & 2.1 & 0 & $37.5 *$ & $33.4 *$ & 18.3 & .40 \\
\hline & c & .0372 & $9.3 *$ & 6.1 & 0 & 0 & $75.8 *$ & 8.8 & .73 \\
\hline Th--.-- & A & .0094 & $17.7 *$ & 5.5 & 0 & $29.2 \star$ & 23.5 & 24.1 & 1.0 \\
\hline & $\mathrm{c}^{2}$ & .0208 & $13.3 *$ & 0 & 2.2 & 16.5 & 17.1 & 509 & .54 \\
\hline $\mathrm{Ti}^{2}-$ & $A$ & 0023 & 0 & 11.2 & 0 & $39.9 *$ & $32.2 *$ & 16.7 & .41 \\
\hline & c & .0041 & 1.3 & 0 & 6.4 & 0 & $87.4 *$ & 4.9 & .05 \\
\hline U----- & A & .0131 & $31.7 *$ & $10.2 *$ & 0 & 18.0 & $37.6 *$ & 2.5 & 2.5 \\
\hline & c & 0288 & $17.7^{*}$ & 0 & 10.6 & 11.5 & $57.9 *$ & 2.3 & .68 \\
\hline v----- & A & .0171 & $7.3 *$ & 0 & 3.1 & 12.6 & 22.1 & 54.9 & .28 \\
\hline & c & .0449 & $10.7 *$ & 0 & $17.5 *$ & 0 & $606 *$ & 11.2 & .37 \\
\hline Y---- & A & .0369 & 2.2 & 7.1 & 0 & 0 & 47.2 & 43.5 & .41 \\
\hline & c & .0361 & 0 & 0 & 0 & $30.9 *$ & 29.1 & 40.1 & 0 \\
\hline Yb-...- & A & .0296 & $6.4^{*}$ & 0 & 9.0 & 0 & 3.3 & 81.3 & .24 \\
\hline & $\mathrm{c}$ & 0347 & 1.2 & 0 & 0 & $26.7 \star$ & 24.5 & 47.6 & .04 \\
\hline $2 n \ldots$ & A & 540.2 & 3.3 & $19.0^{*}$ & 0 & 13.4 & $62.4 *$ & 1.9 & 1.1 \\
\hline & c & 413.5 & 0 & 0 & 10.7 & 0 & $74.9 *$ & 14.4 & 0 \\
\hline $2 \mathrm{r}-\cdots$ & A & .0594 & $4.6 *$ & 88 & 0 & 10.0 & 0 & 76.6 & .59 \\
\hline & c & 0406 & 0 & 5.0 & 4.2 & 0 & 22.9 & 67.9 & 2.0 \\
\hline
\end{tabular}

\footnotetext{
IVariance mean ratio of Miesch (1976a).
}

${ }^{2}$ variance computed on arithmetic basis. 
Basin of Wyoming (fig. 1) showed a significant portion of the total variation to be at distances of from 0.3 to $1 \mathrm{~km}$ for many of the elements evaluated in this study.

Each variance component was tested against the null hypothesis that the component does not significantly differ from zero using the conventional F-test at the 0.05 probability level (table 2). If a component fails to differ from zero, then it is impractical to map the observed variation over intervals associated with that component because of the high probability that no variation exists. On the other hand, a significant variance component at the terrain level suggests that the concentrations of elements in samples from one terrain differ from those of the other terrain.

Our principal interest is in using variance components to calculate the variance mean ratio, to calculate the minimum number of samples required to estimate a cell mean with a given degree of certainty, and to determine the presence and magnitude of regional variance as a basis for making regional maps. (We define "regional variance" as variation that occurs between areas of $100-\mathrm{km}$ on a side or greater.) The large local variation indicates that mapping within smaller areas would require an excessive number of samples and would result in more map detail than is necessary.

\section{VARIANCE MEAN RATIO}

The variance mean ratio, $v_{m}$, of Miesch (1976a) provides an index of the relative stability of an estimate of the mean for any cell size on the basis of the data already collected. In particular, we use $v_{\mathrm{m}}$ (table 1) to evaluate the feasibility of mapping the regional distribution of total concentration of elements in soil. The equation for $v_{m}$ has been modified from that of Miesch (1976a) to account for the unbalanced, nested design, as follows:

$$
v_{m}=\frac{s_{\alpha}{ }^{2}+s_{\beta}{ }^{2}}{n_{\gamma} s_{\gamma}{ }^{2}+n_{\delta} s_{\delta}^{2}+n\left(s_{\eta}{ }^{2}+s_{\epsilon}{ }^{2}\right)}
$$

where the numerator is the variance between $100-\mathrm{km}$ cells and the denominator is the variance within $100-\mathrm{km}$ cells. The $s_{i}$ 's are the variance components at each level,

TABLE 2.-Unbalanced, nested, analysis-of-variance design used in the Northern Great Plains coal region

\begin{tabular}{|c|c|c|c|c|c|c|}
\hline Level & Source of variation & $\begin{array}{l}\text { Degrees of } \\
\text { freedom }\end{array}$ & Mean square estimates ${ }^{1}$ & F-ratio ${ }^{2}$ & & $\begin{array}{l}\text { Variance } \\
\text { component }\end{array}$ \\
\hline 1 & Between terrains & 1 & $\mathrm{MS}_{1}=\mathrm{s}_{\varepsilon}^{2}+1.2 \mathrm{~s}_{\eta}^{2}+1.8 \mathrm{~s}_{\delta}^{2}+2.8 \mathrm{~s}_{\gamma}^{2}+4.5 \mathrm{~s}_{\beta}^{2}+68.6 \mathrm{~s}_{\alpha}^{2}$ & $\mathrm{MS}_{1} / \mathrm{MS}_{2}$ & $\mathrm{~s}_{\alpha}^{2}=$ & $\frac{M S_{1}-M S_{2}}{68.6}$ \\
\hline 2 & $\begin{array}{l}\text { Between } 100-\mathrm{km} \text { cell } \mathrm{s} \\
\text { within terrains }\end{array}$ & 32 & $\mathrm{MS}_{2}=\mathrm{s}_{\varepsilon}^{2}+1.1 \mathrm{~s}_{\eta}^{2}+1.7 \mathrm{~s}_{\delta}^{2}+2.7 \mathrm{~s}_{\gamma}^{2}+4.3 \mathrm{~s}_{B}^{2}$ & $\mathrm{MS}_{2} / \mathrm{MS}_{3}$ & $s_{B}^{2}=$ & $\frac{\mathrm{MS}_{2}-\mathrm{MS}_{3}}{4.3}$ \\
\hline 3 & $\begin{array}{l}\text { Between } 50-\mathrm{km} \text { cells } \\
\text { within } 100-\mathrm{km} \text { cell s }\end{array}$ & 34 & $M S_{3}=s_{\varepsilon}^{2}+1.1 s_{\eta}^{2}+1.3 s_{\delta}^{2}+1.6 s_{\gamma}^{2}$ & $\mathrm{MS}_{3} / \mathrm{MS}_{4}$ & $s_{\gamma}^{2}=$ & $\frac{\mathrm{MS}_{3}-\mathrm{MS}_{4}}{1.6}$ \\
\hline 4 & $\begin{array}{l}\text { Between } 10-\mathrm{km} \text { cell s } \\
\text { within } 50-\mathrm{km} \text { cell } \mathrm{s}\end{array}$ & 34 & $\mathrm{MS}_{4}=\mathrm{s}_{\varepsilon}^{2}+\mathrm{s}_{\eta}^{2}+1.4 \mathrm{~s}_{\delta}^{2}$ & $\mathrm{MS}_{4} / \mathrm{MS}_{5}$ & $\mathrm{~s}_{\delta}^{2}=$ & $\frac{\mathrm{MS}_{4}-\mathrm{MS}_{5}}{1.4}$ \\
\hline 5 & $\begin{array}{l}\text { Between } 1-\mathrm{km} \text { cell } \mathrm{s} \\
\text { within } 10-\mathrm{km} \text { cell } \mathrm{s}\end{array}$ & 34 & $\mathrm{MS}_{5}=\mathrm{s}_{\varepsilon}^{2}+1.1 \mathrm{~s}_{\eta}^{2}$ & $\mathrm{MS}_{5} / \mathrm{MS}_{6}$ & $s_{n}^{2}=$ & $\frac{\mathrm{MS}_{5}-\mathrm{MS}_{6}}{1.1}$ \\
\hline \multirow[t]{3}{*}{6} & Between analyses of: & & & & & \\
\hline & $\begin{array}{c}\text { A-horizons within } \\
l-k m \text { cells }\end{array}$ & 12 & $\mathrm{MS}_{6}=\mathrm{s}_{\varepsilon}^{2}$ & ----- & & $s_{\varepsilon}^{2} \cong \sigma_{\varepsilon}^{2}$ \\
\hline & $\begin{array}{c}\text { C-horizons within } \\
1-\mathrm{km} \text { cells }\end{array}$ & 16 & $M S_{6}=s_{\varepsilon}^{2}$ & ------ & & $s_{\varepsilon}^{2} \cong \sigma_{\varepsilon}^{2}$ \\
\hline
\end{tabular}

\footnotetext{
${ }^{1}$ Mean-square estimates are for A horizons; the coefficients for C horizons may vary by 0.1 unit because of the different numbers of samples for $A$ and $C$ horizons at the "Between analyses" level.

${ }^{2}$ Leaders (--), no F-ratio exists.
} 
and the $n_{i}$ 's are coefficients that represent the average number of samples in each level. These coefficients are developed from a more general expression of Leone and others $(1968$, p. 725$)$. A value of 1.0 , which is taken as a threshold value, is approximately equivalent to an F-test at the 80 percent probability level. For values of $v_{m}$ less than about one, a map of total concentration of an element in soil, based on limited sampling, tends not to faithfully reproduce the true chemical pattern (Miesch, 1976b, p. 102). As $v_{m}$ increases beyond 1.0, however, a map based on limited sampling reveals more clearly the true chemical pattern. The observed values of $v_{m}$ range from a low of zero to a high of 3.3 (table 1). Eight elements in the $\mathrm{A}$ horizon and eight in the $\mathrm{C}$ horizon have a $v_{m}$ greater than one and, therefore, these data are presented cartographically.

\section{ELEMENT-DISTRIBUTION SUMMARIES}

The decision as to which method of reporting the distributions of element concentrations is best depends on the magnitude of variation present in the data. A distribution map based on the means of rather small areas is the most ideal display, because the element concentrations can be related to geographic locations. However, this requires highly reproducible data. Where such data are not available, then the means must be summarized over larger areas, with the result that local differences tend to disappear. The data have been subdivided, therefore, into five groups on the basis of variance components at the terrain, $100-\mathrm{km}-\mathrm{cell}$, and analytical-error levels, and on the basis of whether or not the variance-mean ratio exceeds the threshold of 1.0 .

The five distinct groups of elements are presented in table 3. Group-1 elements are those that exhibit a significant variance component at either the terrain or the $100-\mathrm{km}$-cell level and that have a $v_{m}>1.0$. For these elements, we can prepare reliable maps of their concentration in soil on the basis of the means of samples within each $100-\mathrm{km}$ cell. These maps represent values from a minimum of 22 percent of the total observed arithmetic variation ( $\mathrm{Zn}$ in $\mathrm{A}$ horizons) to a maximum of 46 percent of the total observed logarithmic variation $(C$ in A horizons). Maps showing regional distribution of amounts of 15 elements in soil are presented in figures $6 A$ through $6 Q$. The resolution, or the amount of detail, is dependent on the sampling interval (cell size) shown on the map. Greater resolution and increasing detail of element distributions in soil can be obtained if the mapping interval is decreased to 50,10 , and $1 \mathrm{~km}$, respectively, and if a significant variance component is associated with each of these smaller geographic scales. However, the reliability of data on maps of smaller areas will depend on the variance mean ratio (Eq. 3). For example, mapping $\mathrm{Ge}$ in the $\mathrm{C}$ horizon of a $10-\mathrm{km}$ unit would result in no increase in either reliability or resolution over mapping a 100-km unit, because the components of variance at 50 and $10 \mathrm{~km}$ are both zero (table 1). However, mapping $\mathrm{K}$ in the $\mathrm{C}$ horizon at a 50 - rather than a $100-\mathrm{km}$ unit should enhance both the reliability and the resolution of the map, because the variance component at $50 \mathrm{~km}$ is significant and it accounts for an additional 21.6 percent of the total variation. The value of $v_{m}$ is increased from 1.7 (100-km unit) to 5.3 (50-km unit); the resulting map of $\mathrm{K}$ in the $\mathrm{C}$ horizon would be much more reliable. The variation explained by the map based on $100-\mathrm{km}$ units is 39.6 percent of the total variation and would be 61.2 percent of the total variation for a map based on a $50-\mathrm{km}$ unit. In addition, the map of a $50-\mathrm{km}$ unit would show more detail of the element distribution than the map of a $100-\mathrm{km}$ unit. However, maps of less than $100-\mathrm{km}$ units are not presented because of the nature of our unbalanced sampling design and the resulting distribution of data points.

The entries in Groups 2, 3, and 4 (table 3) have a $v_{\mathrm{m}}<1.0$ and, therefore, the lines on a map for any of these elements would not be considered reliable when compiled for a $100-\mathrm{km}$ unit using the present data. Group-2 elements exhibit significant variance components at the terrain level but not at the 100-km-cell level (table 3). For these elements, the means and expected ranges in concentration of the samples within each terrain give the best estimate of element distribution in soil for the area. This type of estimate has been referred to as a "regional geochemical baseline" by Tidball and Ebens (1976). The baselines for elements of Group 2 are presented in table 4 for each of the two terrains, glaciated and unglaciated. The expected range is computed after adjusting the gross deviation for analytical error, which makes up a portion of the gross deviation (Connor, 1976). An estimate was also computed for $n_{r}$, the number of random samples needed within each $100-\mathrm{km}$ cell to raise the value of $v_{m}$ to 1.0 and, thereby, provide data that can be expressed by a reliable map.

Group-4 elements have no significant variance component at either the terrain or the $100-\mathrm{km}$-cell levels (table 3). A single estimate of the mean and expected range for each of these elements over the entire study area is the best estimate of a baseline. The estimates are presented in table 5. The value of the baseline for each element in Groups 2 and 4 represents an expected range in concentration that we consider to be of use in making extrapolations from one location to another, either over the entire study area (Group-4 elements) or within the area of each terrain (Group-2 elements). In addition, any new data may be compared to the baseline to identify extreme values in element concentration. 
TABLE 3.-Grouping of elements based on significant variance components $\left(s_{\alpha \cdot \beta}{ }^{2}\right)$, variance mean ratios $\left(v_{m}\right)$, and analytical-error variance $\left(s_{\varepsilon}{ }^{2}\right)$ [Asterisk indicates significance at the 0.05 probability level. (---) indicates no element included in that grouping]

\begin{tabular}{|c|c|c|c|c|c|c|}
\hline \multirow{3}{*}{$\begin{array}{c}100-\mathrm{km} \\
\mathrm{ce} 11\end{array}$} & \multirow{3}{*}{$\begin{array}{c}\text { Soil } \\
\text { horizon }\end{array}$} & \multirow{2}{*}{$\frac{\mathrm{v}_{\mathrm{m}}>1.0}{\text { Group } 1}$} & \multicolumn{3}{|c|}{$\mathrm{v}_{\mathrm{m}}<1.0$} & \multirow{2}{*}{$\frac{\frac{s^{2}}{s^{2}} 50 \text { pct. }}{\text { Group } 5}$} \\
\hline & & & Group 2 & Group 3 & Group 4 & \\
\hline & & \multicolumn{5}{|c|}{ Terrain, $s_{\alpha}^{2 *}$} \\
\hline$s_{\beta}^{2} *$ & $\begin{array}{l}\mathrm{A} \\
\mathrm{C}\end{array}$ & $\begin{array}{ll}C, & \mathrm{Rb}, \mathrm{U} \\
\mathrm{C}, \mathrm{Mg}\end{array}$ & -- & --- & --- & F \\
\hline \multirow[t]{3}{*}{$\mathbf{s}_{B}^{2}$} & A & $\mathrm{K}, \mathrm{Th}$ & $\begin{array}{l}\mathrm{Al}, \mathrm{Be}, \mathrm{Hg}, \\
\mathrm{Mn}, \mathrm{Se}, \mathrm{Sr},\end{array}$ & -- & -- & $\mathrm{Yb}, \mathrm{Zr}$ \\
\hline & C & $\mathrm{Ca}, \mathrm{K}, \mathrm{Rb}$ & $\begin{array}{l}\mathrm{Al}, \mathrm{Ga}, \mathrm{Mn}, \\
\mathrm{Ni}, \mathrm{Si}, \mathrm{Sr}, \\
\mathrm{U}, \mathrm{V}\end{array}$ & --- & --- & Th, V \\
\hline & & \multicolumn{5}{|c|}{$\begin{array}{r}\text { Terrain, } s^{2} \\
\alpha \\
\end{array}$} \\
\hline$s_{B}^{2 *}$ & $\begin{array}{l}\mathrm{A} \\
\mathrm{C}\end{array}$ & $\begin{array}{l}\mathrm{Na}, \mathrm{Si}, \mathrm{Zn} \\
\mathrm{As}, \mathrm{Ge}\end{array}$ & --- & $\begin{array}{l}\mathrm{Ca}, \mathrm{Fe}, \mathrm{Ge} \\
\mathrm{Mo}, \mathrm{Ni}\end{array}$ & --- & $\begin{array}{l}\mathrm{Cr} \\
\mathrm{Ba}\end{array}$ \\
\hline $\mathrm{s}_{B}^{2}$ & A & --- & -- & --- & $\begin{array}{l}\text { As, } \mathrm{B}, \mathrm{Ca}, \\
\mathrm{Co}, \mathrm{Ga}, \mathrm{Li}, \\
\mathrm{Mg}, \mathrm{Sn}, \mathrm{Ti}, \\
\mathrm{Y}\end{array}$ & $\begin{array}{l}\mathrm{Ba}, \mathrm{La}, \mathrm{Nb}, \\
\mathrm{P}, \mathrm{Pb}, \mathrm{Sb}, \\
\mathrm{Sc}\end{array}$ \\
\hline & C & --- & -- & -- & $\begin{array}{l}\mathrm{B}, \mathrm{Be}, \mathrm{Co}, \\
\mathrm{Cr}, \mathrm{Cu}, \mathrm{Fe}, \\
\mathrm{Hg}, \mathrm{La}, \mathrm{Li}, \\
\mathrm{Mo}, \mathrm{Na}, \mathrm{Pb}, \\
\mathrm{Sn}, \mathrm{Ti}, \mathrm{Y}, \\
\mathrm{Yb}, \mathrm{Zn}_{\mathrm{n}}\end{array}$ & $\begin{array}{l}\mathrm{F}, \mathrm{Nb}, \mathrm{P}, \\
\mathrm{Sb}, \mathrm{Sc}, \mathrm{Se}, \\
\mathrm{Zr}\end{array}$ \\
\hline
\end{tabular}

Group-3 elements (table 3) exhibit a significant component of variance between $100-\mathrm{km}$ cells but not between terrains. The regional distribution of these elements, therefore, is best estimated by each $100-\mathrm{km}$-cell mean. These means are both given in table 5 and plotted on maps in figures $6 P-6 T$. The values on the maps are not contoured because the data are judged to be unreliable $\left(v_{m}<1.0\right)$.

Group-5 elements (table 3) exhibit excessive analytical error. Therefore, no interpretation is presented for these elements.

FIGURE 6 (following pages)-Regional distribution of elements in A and C horizons of soils of the Northern Great Plains coal region. Values are means of cells $100-\mathrm{km}$ on a side. Contour lines for figures $A$ through $O$ are the geometric mean (GM) or the arithmetic mean (AM) and the upper or lower expected 95 -percent values. No contours are given for figures $P$ through $T$ because the analysis of variance indicates that such contour lines would tend not to be reproducible. 

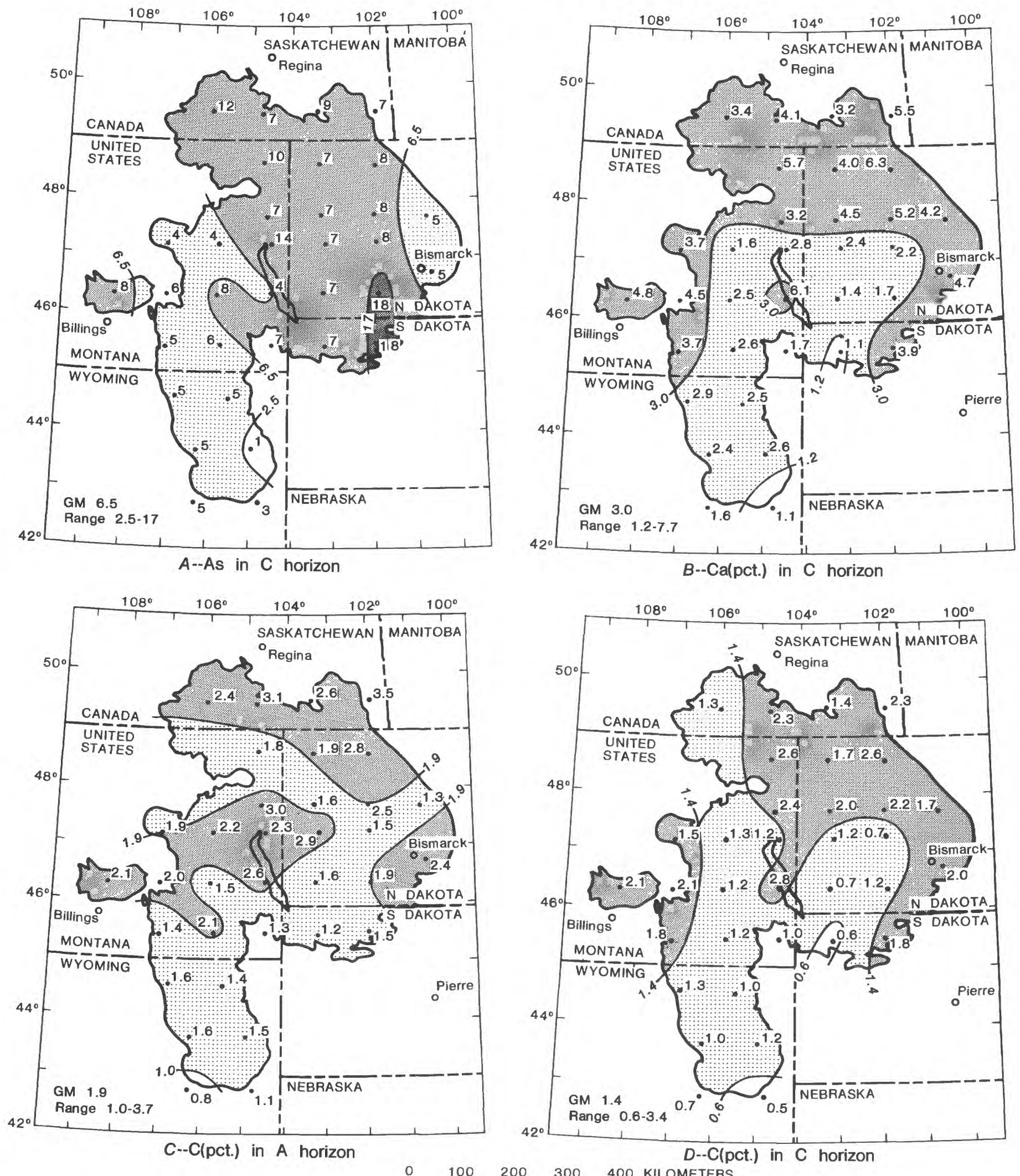

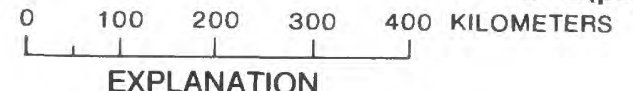

Frequency distribution, in percent

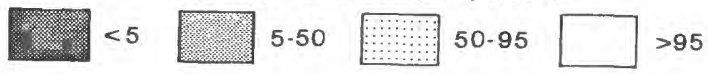

Figure 6.-Continued 
VARIATION IN ELEMENT CONCENTRATION, NORTHERN GREAT PLAINS COAL REGION
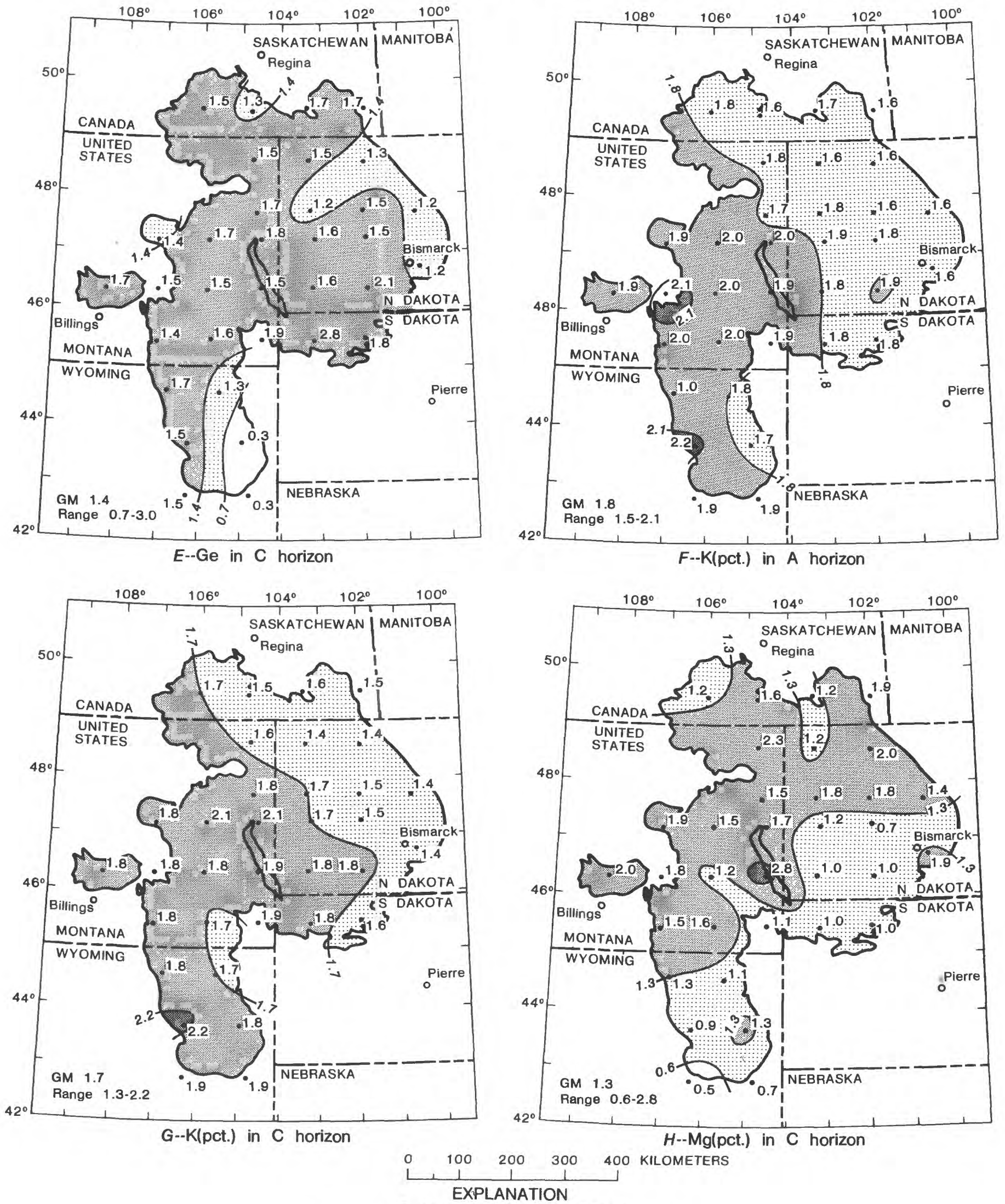

$\frac{0+100 \quad 200 \quad 300}{\text { EXPLANATION }}$

Frequency distribution, in percent

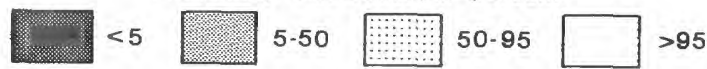

FIGURE 6.-Continued 


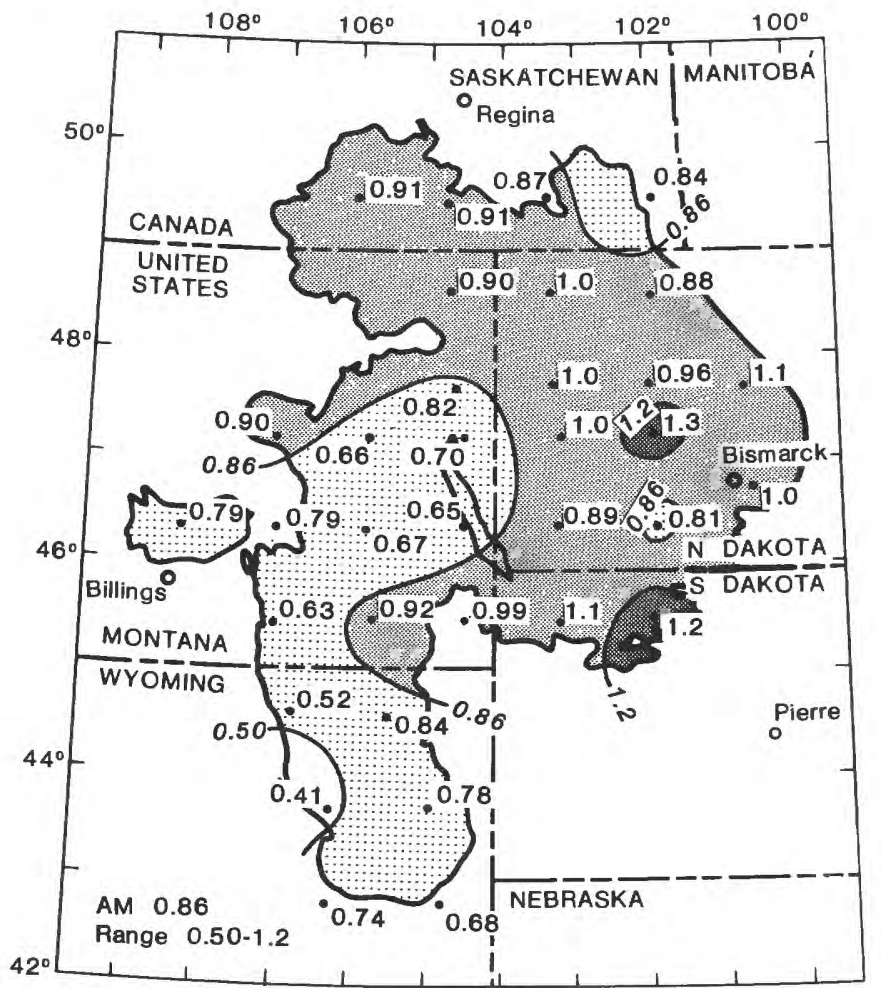

1-- Na(pct.) in A horizon

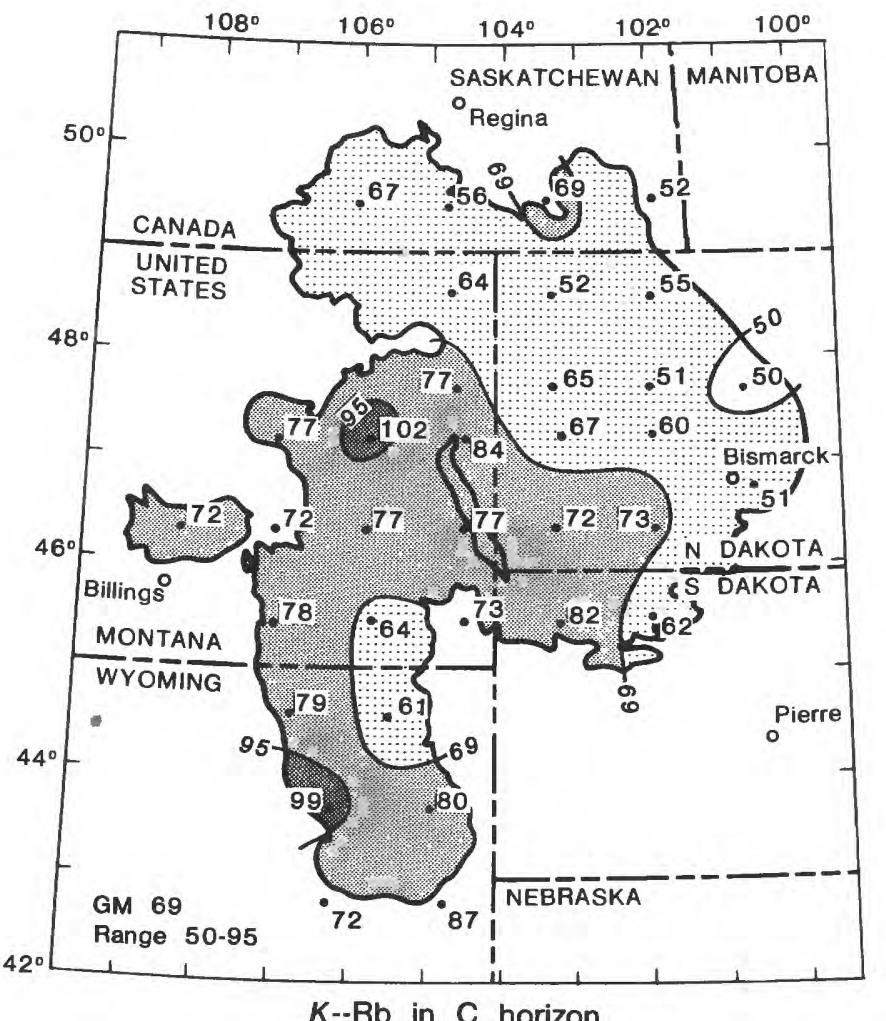

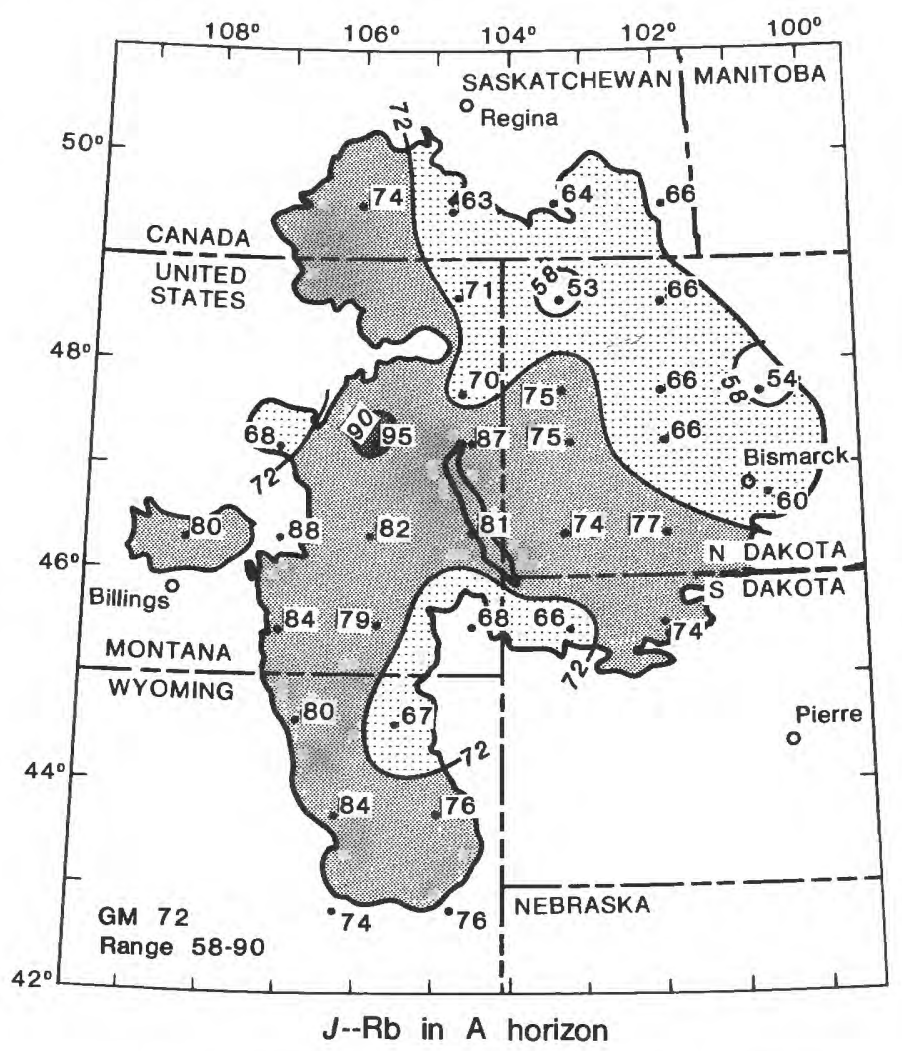

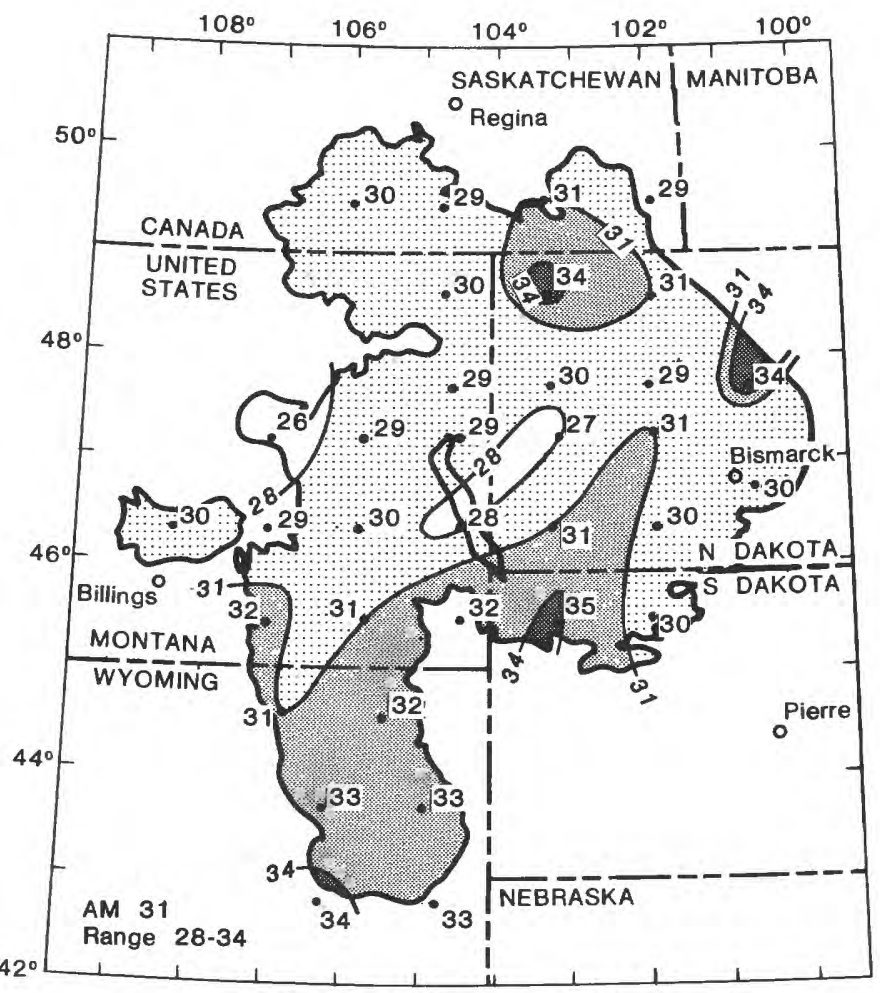

$L$--Si(pct.) in A horizon

o $100 \quad 200 \quad 300 \quad 400$ KILOMETERS

EXPLANATION

Frequency distribution, in percent

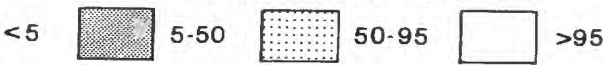

Figure 6.-Continued 
VARIATION IN ELEMENT CONCENTRATION, NORTHERN GREAT PLAINS COAL REGION

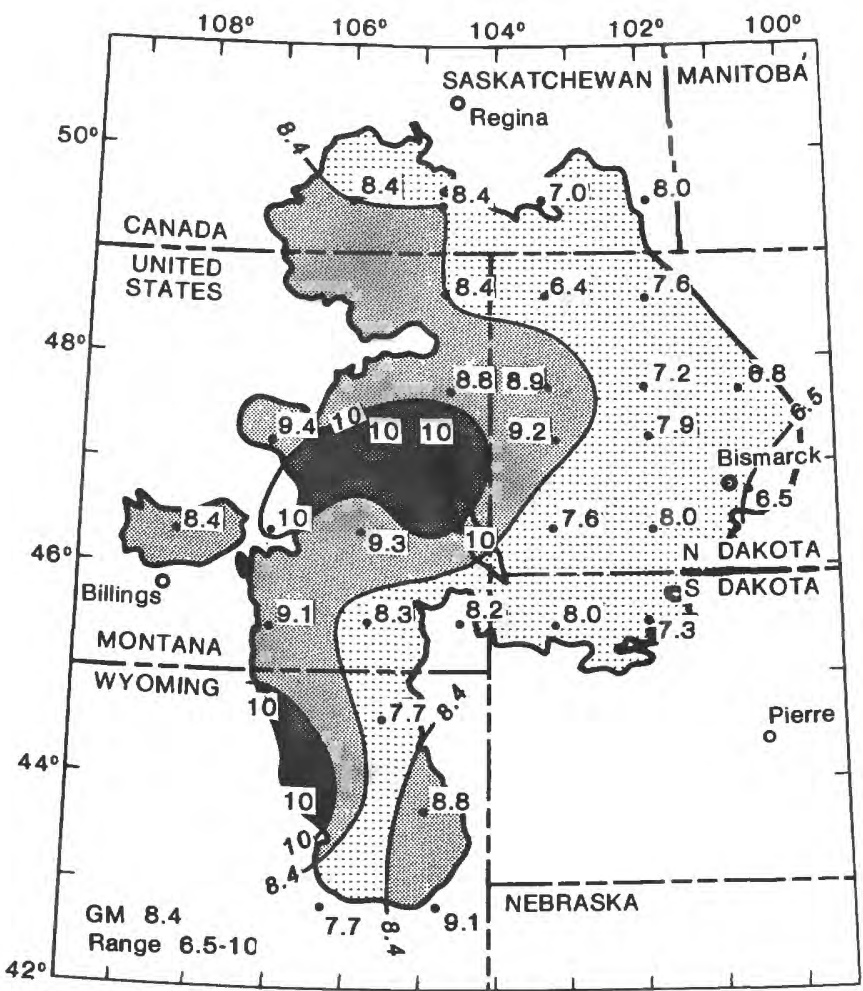

$M-$ Th in A horizon

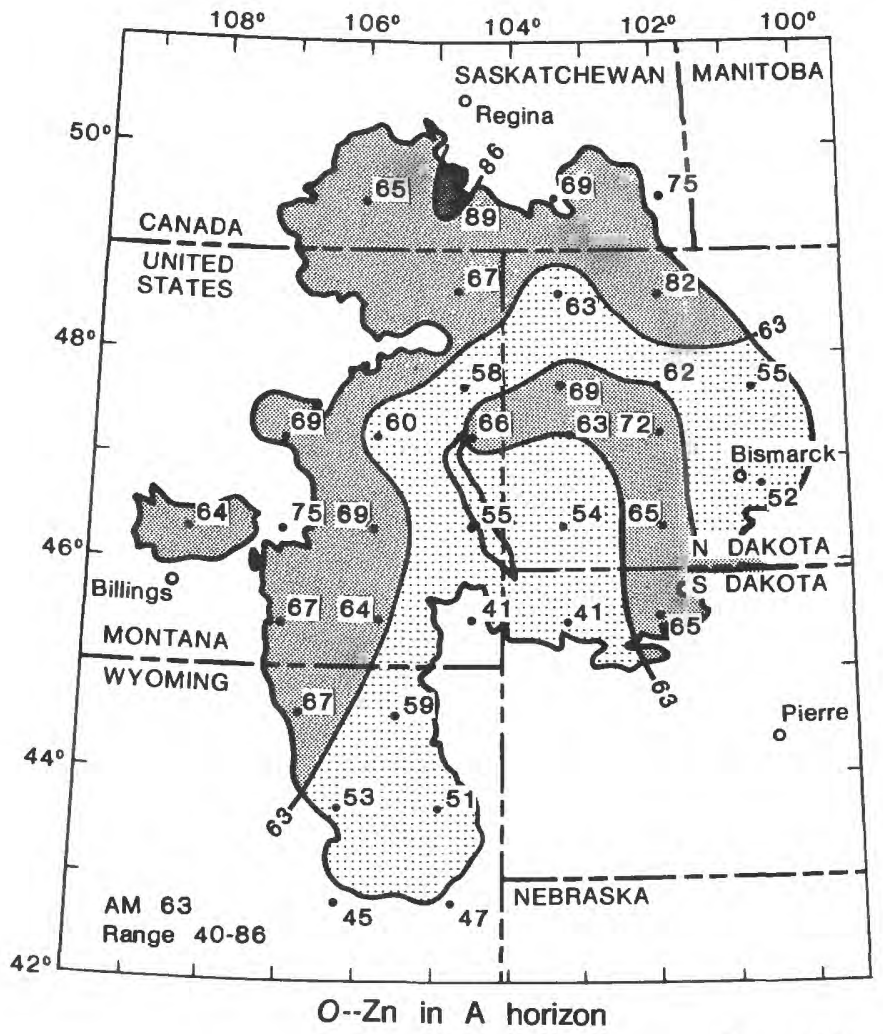

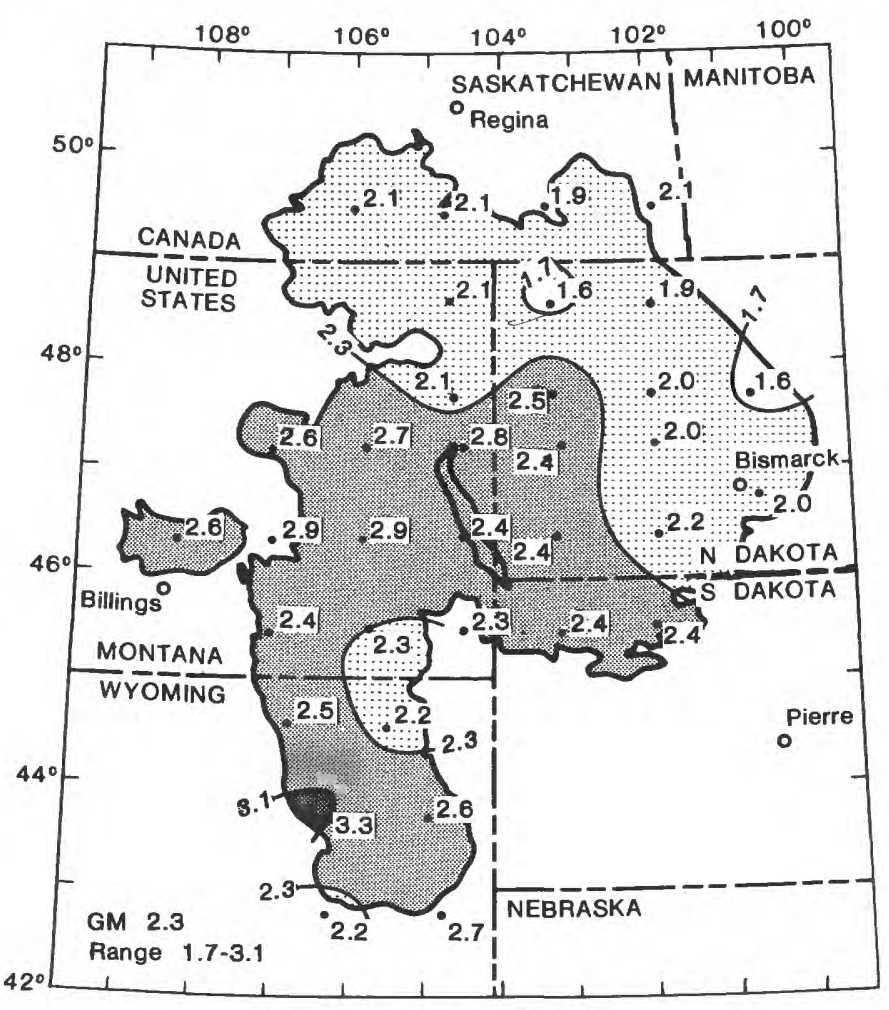

$\mathrm{N}-\mathrm{-U}$ in A horizon

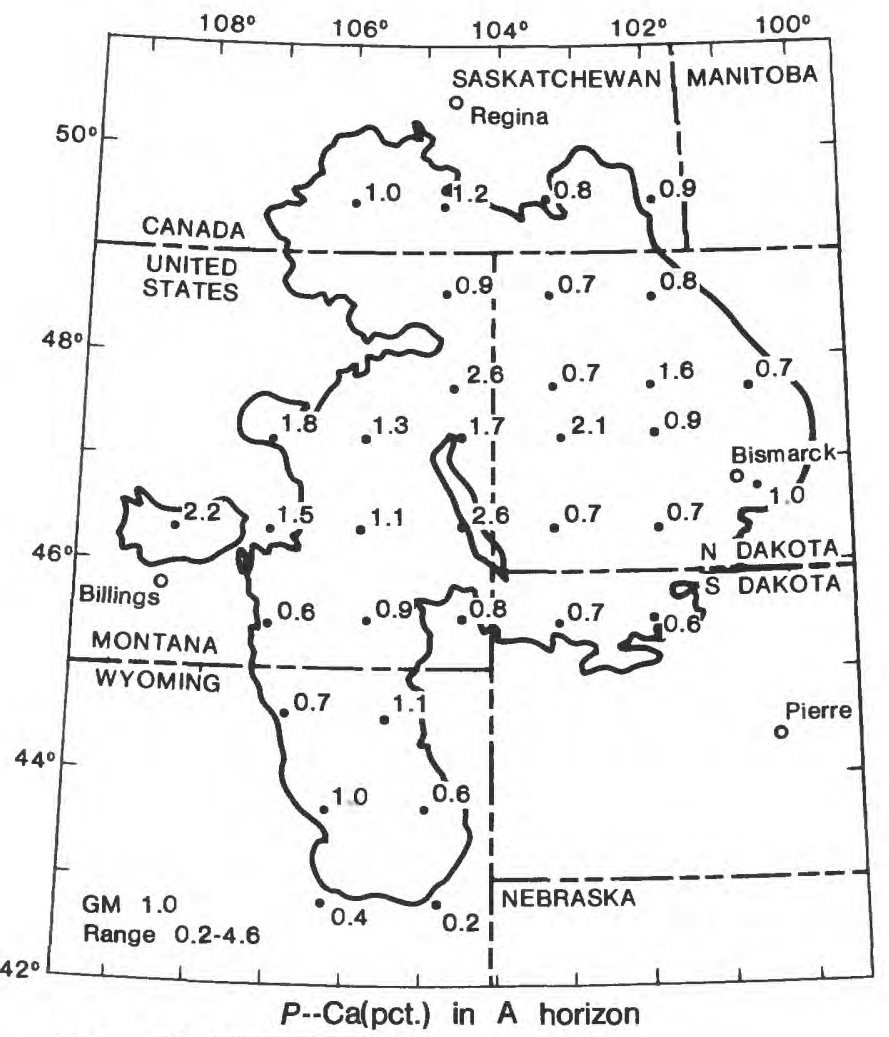

$0 \quad 100 \quad 200 \quad 300 \quad 400$ KILOMETERS

EXPLANATION

Frequency distribution, in percent

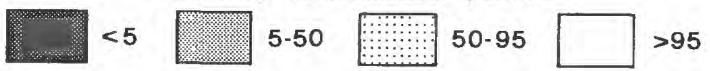

Figure 6.-Continued 

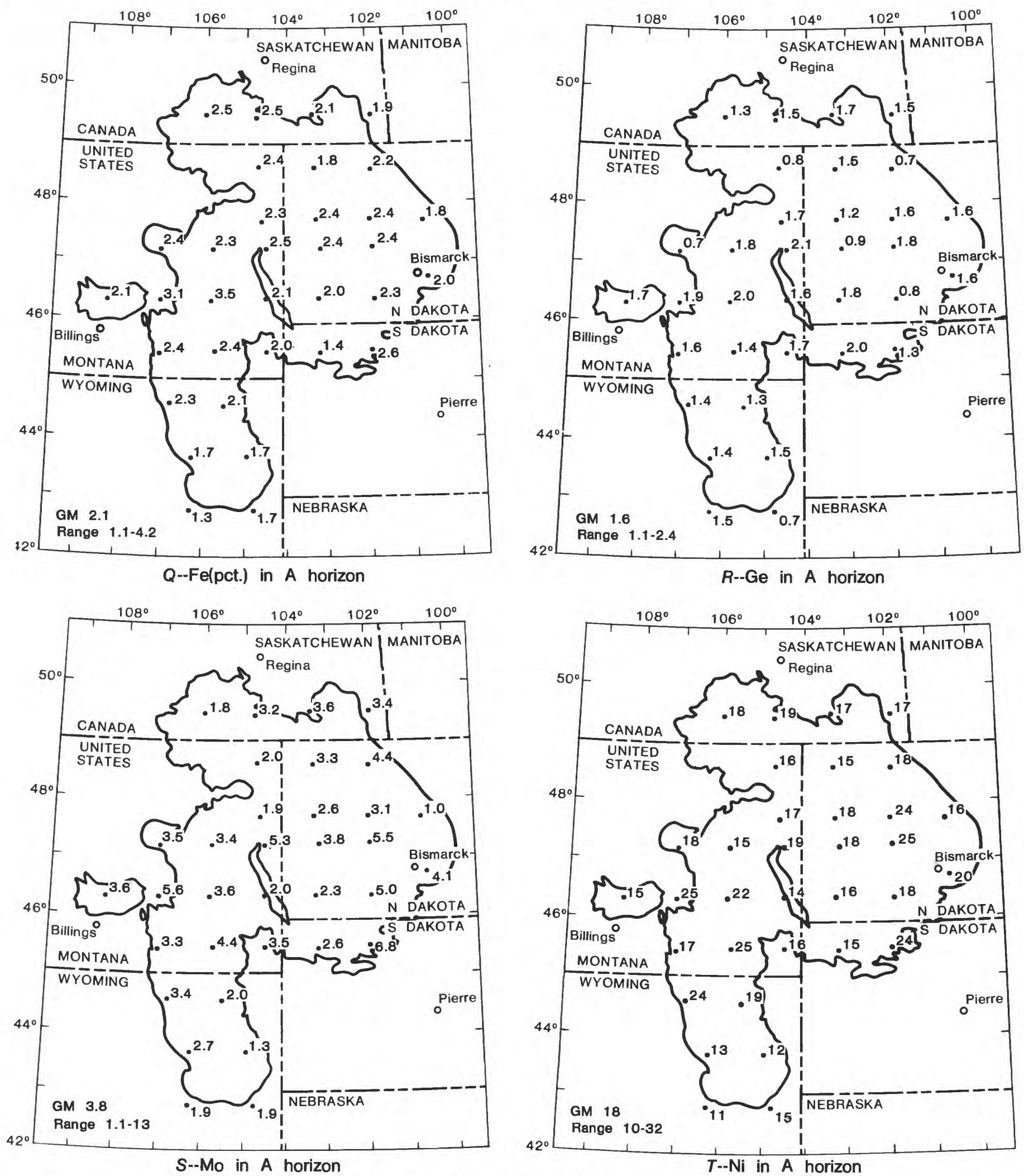

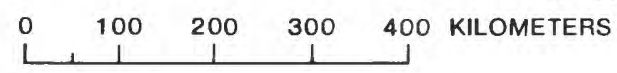

$T--\mathrm{Ni}$ in A horizon

Figure 6.-Continued 
TABLE 4.-Chemical summaries for elements in soil that exhibit a significant variance component between terrains of the Northern Great Plains coal region (Group-2 elements)

[G. glaciated terrain; U. unglaciated terrain. *. element measured in percent; other elements measured in parts per million except $\mathrm{Hg}$. parts per billion]

\begin{tabular}{|c|c|c|c|c|c|c|c|c|c|c|c|}
\hline \multirow[t]{2}{*}{ Element } & \multirow{2}{*}{$\begin{array}{c}\text { Soil } \\
\text { horizon }\end{array}$} & \multicolumn{2}{|c|}{$\begin{array}{c}\text { Geometric } \\
\text { mean }\end{array}$} & \multicolumn{2}{|c|}{$\begin{array}{l}\text { Geometric } \\
\text { deviation }\end{array}$} & \multirow{2}{*}{$\begin{array}{c}\text { Geometric } \\
\text { error }\end{array}$} & \multicolumn{4}{|c|}{ Baseline value ${ }^{l}$} & \multirow{2}{*}{$n_{r}^{2}$} \\
\hline & & G & $\mathrm{U}$ & G & $\mathrm{U}$ & & & G & & $\mathrm{U}$ & \\
\hline \multirow[t]{2}{*}{$\mathrm{A} 1 *----$} & A & 5.3 & 5.8 & 1.17 & 1.18 & 1.09 & $4.1-$ & 6.9 & 4.4. & 7.7 & 7 \\
\hline & $\mathrm{C}$ & 5.3 & 5.9 & 1.22 & 1.22 & 1.06 & $3.6-$ & 7.8 & 4.0 & 8.6 & 7 \\
\hline $\mathrm{Be}-----$ & A & 1.5 & 1.7 & 1.46 & 1.38 & 1.27 & $0.8-$ & 2.6 & 1.1 & 2.6 & 11 \\
\hline $\mathrm{Ga}-----$ & $\mathrm{C}$ & 10 & 11 & 1.58 & 1.51 & 1.33 & 5 & -21 & 6 & -21 & 34 \\
\hline $\mathrm{Hg}-----$ & A & 26 & 21 & 1.40 & 1.48 & 1.05 & 13 & -51 & 9 & -44 & 7 \\
\hline \multirow[t]{2}{*}{ Mn----- } & A & 720 & 330 & 1.83 & 2.76 & 1.81 & 570 & -910 & 60 & -1700 & 5 \\
\hline & $\mathrm{C}$ & 440 & 180 & 2.37 & 4.20 & 1.79 & 120 & -1600 & 10 & -2500 & 8 \\
\hline $\mathrm{Ni}----$ & $\mathrm{C}$ & 22 & 18 & 1.44 & 1.67 & 1.24 & 12 & $-\quad 40$ & 7 & -46 & 16 \\
\hline $\mathrm{Se}----$ & A & .5 & .4 & 2.45 & 2.93 & 2.18 & $0.2-$ & 1.1 & 0.1 & 1.9 & $\mathrm{n} \cdot \mathrm{d} \cdot{ }^{3}$ \\
\hline$S i *^{4}--$ & $\mathrm{C}$ & 27 & 29 & 2.74 & 3.59 & 1.22 & 22 & -32 & 22 & -36 & 5 \\
\hline \multirow[t]{2}{*}{ Sr---- } & A & 180 & 150 & 1.24 & 1.54 & 1.18 & 140 & -240 & 70 & -340 & 7 \\
\hline & $\mathrm{C}$ & 240 & 190 & 1.24 & 1.56 & 1.14 & 170 & -380 & 80 & -450 & 6 \\
\hline U----- & $\mathrm{C}$ & 2.2 & 2.8 & 1.42 & 1.41 & 1.06 & $1.1-$ & $-\quad 1.4$ & 1.4 & $+\quad 5.5$ & 5 \\
\hline V------ & $\mathrm{C}$ & 64 & 50 & 1.45 & 1.43 & 1.18 & $33-$ & -120 & 26 & - 99 & 7 \\
\hline
\end{tabular}

${ }^{1}$ Expected $95-$ percent range.

${ }^{2}$ Minimum number of random samples per $100-\mathrm{km}$ cell needed to map regional variation.

${ }^{3}$ Not determined.

${ }^{4}$ Values computed on arithmetic basis.

\section{DIFFERENCES BETWEEN SOIL HORIZONS}

In the unbalanced, nested, analysis-of-variance design, the sixth (or lowest) level consists of samples that were analyzed in duplicate to estimate variation associated with sample preparation and analysis (table 2). This was done because splits of a single sample, when subjected to repeated chemical analysis, do not yield identical results. The variance associated with sample preparation and analysis should be estimated and included as part of the total variation observed in a sample of a population, because, in some cases, it exceeds the variation from any other source.

Initially each element was assumed to have a common analytical-error variance that could be estimated from sample determinations irrespective of soil horizons. Although the reproducibility of a measured value is subject to interferences that arise from differing matrix effects, these effects were expected to be common to both surface and subsurface horizons. However, the possible analytical errors shown in table 1 suggest that, for many elements, the analytical reproducibility differs widely in the two soil horizons. For most elements, the portion of the total observed variance associated with sample preparation and analysis of the A horizon exceeds that of the $\mathrm{C}$ horizon (table 1 ). In fact, logarithmic variance estimates of analytical error for $\mathrm{B}, \mathrm{Ba}, \mathrm{C}, \mathrm{Hg}$, $\mathrm{Li}, \mathrm{Na}, \mathrm{Th}$, and $\mathrm{Zn}$ differ significantly between horizons as indicated by an F-test at the 5 percent probability level. (The F-ratio is computed by dividing the variance of the $\mathrm{A}$ or $\mathrm{C}$ horizon, whichever is larger, by the smaller variance.)

Because the data for 29 elements do not show significant differences in analytical error between horizons, it 
TABLE 5.-Chemical summaries for elements in soil that exhibit a non-significant variance component between terrains of the Northern Great Plains coal regions (Group-3 and -4 elements)

[", element measured in percent; all others measured in parts per million except $\mathrm{Hg}$, parts per billion]

\begin{tabular}{|c|c|c|c|c|c|c|}
\hline Element & $\begin{array}{c}\text { Soil } \\
\text { horizon }\end{array}$ & $\begin{array}{l}\text { Geometric } \\
\text { mean }\end{array}$ & $\begin{array}{l}\text { Geometric } \\
\text { deviat ion }\end{array}$ & $\begin{array}{c}\text { Geometric } \\
\text { error }\end{array}$ & $\begin{array}{l}\text { Basel ine }{ }^{1} \\
\text { value }\end{array}$ & $n_{r}^{2}$ \\
\hline As---- & A & 7.1 & 1.69 & 1.19 & $2.6-19$ & 7 \\
\hline \multirow{2}{*}{ B-- } & $\mathbf{A}$ & 41 & 1.59 & 1.27 & -96 & 9 \\
\hline & C & 43 & 1.61 & & -115 & \\
\hline \multirow{2}{*}{$\begin{array}{l}\mathrm{Be}---- \\
\mathrm{Ca}\end{array}$} & c & 1.6 & 1.44 & 3 & \multirow{2}{*}{$\begin{array}{l}0.6-4.0 \\
0.2-4.6\end{array}$} & n.d. \\
\hline & A & 1.0 & 2.14 & 1.06 & & 5 \\
\hline \multirow[t]{2}{*}{ Co------ } & A & 6.4 & 1.48 & 1.24 & $2.8-14$ & n.d. \\
\hline & C & 6.6 & & & $2.8-16$ & n.d. \\
\hline $\mathrm{Cr}_{\mathbf{r}}-\ldots$ & c & 42 & 1.66 & 1.35 & $\begin{array}{ll}15 & -120\end{array}$ & n.d. \\
\hline \multirow{2}{*}{$\mathrm{Cu}----$} & A & 19 & 1.64 & 1.31 & -43 & n.d. \\
\hline & c & 17 & 1.82 & 1.49 & -52 & n.d. \\
\hline \multirow[t]{2}{*}{$\mathrm{Fe}^{*-\ldots-}$} & A & 2.1 & 1.41 & 1.02 & \multirow{2}{*}{$1.1=4.2$} & 5 \\
\hline & $\mathrm{c}$ & 2.2 & 1.40 & 1.02 & & n.d. \\
\hline Ga-n- & A & 11 & 1. & 1. & \multirow{3}{*}{$\begin{array}{c}6=19 \\
1.1=2.4 \\
10=80\end{array}$} & 28 \\
\hline Ge----- & $A$ & 1.6 & 1. & 1.13 & & 6 \\
\hline Hg----- & c & 27 & 1.74 & 1.12 & & 10 \\
\hline \multirow{3}{*}{$\begin{array}{l}\mathrm{La}-\mathrm{-O} \\
\mathrm{Li}-\mathrm{-}\end{array}$} & c & 23 & 1.55 & 1.38 & $10-51$ & n.d. \\
\hline & A & 19 & & & & 11 \\
\hline & c & 21 & 1.48 & 1.13 & \multirow{2}{*}{$\begin{array}{l}10-46 \\
0.2-1.8\end{array}$} & n.d. \\
\hline \multirow{3}{*}{ Mg*-.-- } & A & .7 & 1.67 & 1.02 & & 14 \\
\hline & A & 3.8 & 1.68 & 1.57 & $1.1-13$ & 9 \\
\hline & c & 4.0 & 1.72 & 1.90 & $0.9-18$ & n.d. \\
\hline $\mathrm{Na}^{4}{ }^{4}--$ & c & .9 & & & $0.2-1.5$ & 9 \\
\hline \multirow{2}{*}{$\begin{array}{l}\mathrm{Ni}----- \\
\mathrm{Pb}-----\end{array}$} & A & 18 & 1. & 1. & & 7 \\
\hline & c & 15 & 1. & 1.59 & \multirow{3}{*}{$\begin{array}{l}5=47 \\
0.3-2.2 \\
0.3-2.8\end{array}$} & n.d. \\
\hline \multirow[t]{2}{*}{ Sn----- } & A & .9 & 1. & 1.51 & & 30 \\
\hline & c & .9 & 1.94 & 1.44 & & 6 \\
\hline \multirow[t]{2}{*}{$T i *^{4}-\cdots$} & A & .25 & .023 & .019 & \multirow[t]{2}{*}{$0.22-0.28$} & 7 \\
\hline & $\mathrm{c}$ & .25 & .058 & .014 & & 32 \\
\hline \multirow[t]{2}{*}{.-- } & A & 18 & 1.46 & 1.34 & 10 & 0 \\
\hline & c & 17 & 1. & 1. & & n.d. \\
\hline rb--... & c & 2.1 & 1.49 & 1.34 & $1.1-3.9$ & n.d. \\
\hline & c & 59 & 19 & 7.7 & $23-94$ & n.d. \\
\hline
\end{tabular}

${ }^{1}$ Expected 95-percent range.

${ }^{2}$ Minimum number of random samples per $100-\mathrm{km}$ cell needed to map regional variation.

${ }^{3}$ Not determined.

${ }^{4} \mathrm{Values}$ computed on arithmetic basis.

appears that some properties or factors in addition to matrix composition are affecting the reproducibility of the analytical determinations. If the analytical technique is at fault, then we would expect that a group of elements determined by a single technique should consistently exhibit either significant or nonsignificant variation between horizons. However, the elements that exhibit significant differences between errors in the two horizons were determined by several procedures (see U.S. Geological Survey, 1975, fig. 2). Therefore, differences in analytical reproducibility between soil horizons are related to matrix effects, analytical methods, and other unknown factors. However, from the data it is not clear which effect dominates.

The investigator should be aware of the possibility of significant analytical variability between soil materials and should plan to account for it. The cost of reducing the analytical variability, however, must be balanced against the cost of deriving an adequate estimate of the analytical variation either by repeated analysis of a sample or by a more precise analytical technique.

Discriminate-function analysis of data was also performed between $\mathrm{A}$ and $\mathrm{C}$ horizons. The results, which are presented in figure 7 , show that an adequate function can be obtained to discriminate between $\mathrm{A}$ and $\mathrm{C}$ horizons using only three variables $(\mathrm{Ca}, \mathrm{Mg}$, and $\mathrm{C})$. In general, a discriminate-function analysis using only trace-element data would be of little value in separating A- from C-horizon samples. For future studies that concentrate on describing the geographic distribution of elements occurring in trace amounts, a more productive use of available resources may be to sample and analyze only a single soil horizon or a composite sample of several soil horizons. Just as much, or possibly more, information useful in constructing maps of element concentration in soil may be obtained in this way as is obtained by dividing available resources between samples of more than one soil horizon.

\section{CONCLUSIONS}

An attempt has been made to determine the spatial variability of soil chemistry in the Northern Great Plains coal region for 41 elements on the basis of their total concentrations in $\mathrm{A}$ and $\mathrm{C}$ horizons. Using an unbalanced, nested, analysis-of-variance design, maps showing dependable data were prepared based on $100-\mathrm{km}$ cells ( $100 \mathrm{~km}$ on a side) for three elements (C, K, and $\mathrm{Rb}$ ) in both $\mathrm{A}$ and $\mathrm{C}$ horizons, for an additional five elements ( $\mathrm{Na}, \mathrm{Si}, \mathrm{Th}, \mathrm{U}$, and $\mathrm{Zn})$ in the $\mathrm{A}$ horizon, and $\mathrm{C}$ horizon. By doubling the number of random samples from four to eight per $100-\mathrm{km}$ cell, an additional 20 elements in either A- or C-horizon soil would be mappable for the $100-\mathrm{km}$ cell. Baseline values can be assigned, however, for elements that were not dependably mappable. The baseline value is a probable range in concentration to be expected in natural soils. The baseline can be applied to soil materials throughout the study area.

Most of the total observed variation in element concentration for most elements is within cells of less than $10 \mathrm{~km}$ on a side. Therefore, while baseline values can be used as an overview, additional sampling is necessary to evaluate local variability.

Repeated analytical determinations on samples of A and $\mathrm{C}$ horizons of soils vary significantly for several elements. It is not clear from the data whether the varying matrix compositions of the samples or the analytical techniques, or both, are responsible for these variations.

Discriminate-function analysis shows that analyses for only three elements ( $\mathrm{Ca}, \mathrm{Mg}$, and $\mathrm{C})$ are needed to adequately distinguish between $\mathrm{A}$ - and $\mathrm{C}$-horizon soil samples in the Northern Great Plains coal region. 


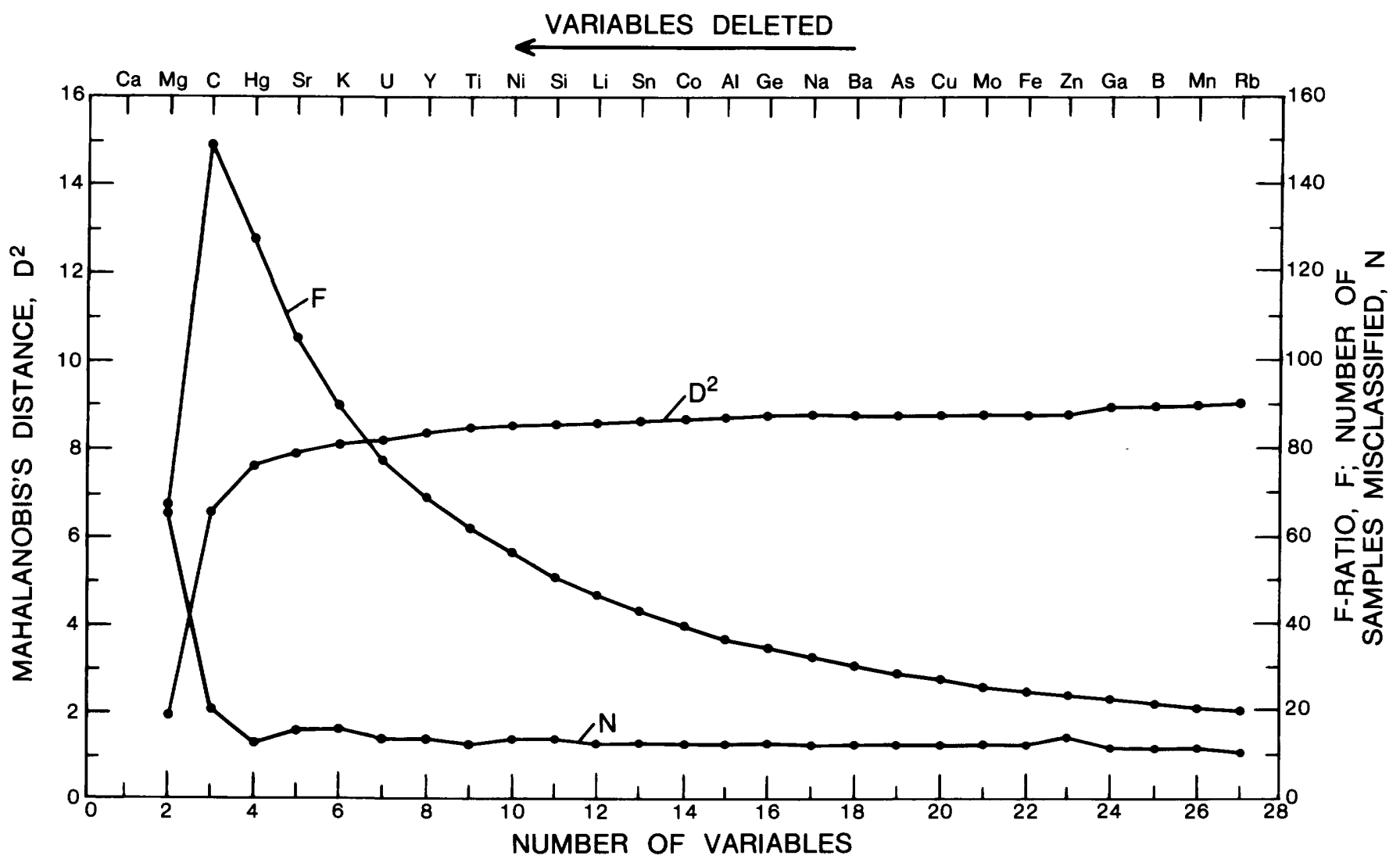

FIGURE 7.-Discriminate function analysis, for elements with analytical error less than 50 percent, between A- and C-horizon samples from the Northern Great Plains coal region.

\section{REFERENCES CITED}

Aandahl, A. R., 1972, Soils of the Great Plains: Published by author, P.O. Box 81242, Lincoln, Nebraska 68508 , scale 1:2,500,000.

Anderson, R. L., and Bancroft, T. A., 1952, Statistical theory in research: New York, McGraw-Hill, 399 p.

Beckett, P. H. T., 1967, Lateral changes in soil variability: The Australian Institute of Agricultural Science Journal, v. 33, p. 172-179.

Beckett, P. H. T., and Webster, R., 1971, Soil variability-a review: Soils and Fertilizers, v. 34, p. 1-15.

Colton, R. B., Lemke, R. W., and Lindvall, R. M., 1961, Glacial map of Montana east of the Rocky Mountains: U.S. Geological Survey Miscellaneous Geologic Investigations Map I-327, scale 1:500,000.

, 1963, Preliminary glacial map of North Dakota: U.S. Geological Survey Miscellaneous Geologic Investigations Map I-331, scale 1:500,000.

Connor, J. J., 1976, A note on the use of geochemical summaries in assessing suspected metal pollution, in U.S. Geological Survey, Geochemical survey of the western energy regions, 3rd annual progress report, July 1976: U.S. Geological Survey Open-file Report 76-729, inside covers.

Connor, J. J., Keith, J. R., and Anderson, B. M., 1976, Trace-metal variation in soils and sagebrush in the Powder River Basin, Wyoming and Montana: U.S. Geological Survey Journal of Research, v. 4, no. 1, p. 49-59.
Crosson, L. S., and Protz, R., 1974, Quantitative comparison, of two closely related soil mapping units: Canadian Journal of Soil Science, v. 54, p. $7-14$.

Denson, N. M., and Chisholm, W. A., 1971, Summary of mineralogical and lithologic characteristics of Tertiary sedimentary rocks in the middle Rocky Mountains and the northern Great Plains, in Geological Survey Research 1971: U.S. Geological Survey Professional Paper 750-C, p. 117-126.

Drees, L. R., and Wilding, L. P., 1973, Elemental variability within a sampling unit: Soil Science Society of America Proceedings, v. 37, p. $82-87$.

Dunnewald, J. J., 1957, Wyoming soils and soils materials, Wyoming University Agricultural Experiment Station Bulletin 349, 24 p.

Erdman, J. A., Shacklette, H. T., and Keith, J. R., 1976, Elemental composition of selected native plants and associated soils from major vegetation-type areas in Missouri: U.S. Geological Survey Professional Paper 954-C, 87 p.

Gill, J. R., and Cobban, W. A., 1973, Stratigraphy and geologic history of the Montana group and equivalent rocks, Montana, Wyoming, and North and South Dakota: U.S. Geological Survey Professional Paper 776, $37 \mathrm{p}$.

Howard, A. D., 1960 [1961], Cenozoic history of northeastern Montana and northwestern North Dakota with emphasis on the Pleistocene: U.S. Geological Survey Professional Paper 326, 108 p.

Hunt, C. B., 1967, Physiography of the United States: San Francisco and London, W. H. Freeman and Co., 480 p. 
Jansen, I. J., and Arnold, R. W., 1976, Defining ranges of soil characteristics: Soil Science Society of America Journal, v. 40, no. 1, p. 89-92.

Keefer, W. R., 1974, Geologic map of the Northern Great Plains, in Regional topography, physiography, and geology of the Northern Great Plains: U.S. Geological Survey Open-file Report 74-50, Plate A-3, scale 1:1,000,000.

Keith, J. R., Anderson, B. M., and Connor, J. J., 1974, Trace metal variation in the Powder River Basin, in Geochemical survey of the western coal regions, 1st annual progress report, July 1974: U.S. Geological Survey Open-file Report 74-250, p. 14-29.

Leone, F. C., Nelson, L. S., Johnson, N. L., and Eisenstat, S., 1968, Empirical studies of unbalanced nested designs, pt. 2 of Sampling distributions of variance components: Technometrics v. 10, no. 4, p. 719-737.

McCormack, D. E., and Wilding, L. P., 1969, Variation of soil properties within mapping units of soils with contrasting substrata in northwestern Ohio: Soil Science Society of America Proceedings, v. 33, p. $587-593$.

McKenzie, R. M., 1955, Sampling variations in the concentrations of elements in soils: Australian Journal of Agricultural Research, $v$. 6, p. 699-706.

Miesch, A. T., 1976a, Geochemical survey of Missouri-methods of sampling, laboratory analysis, and statistical reduction of data with sections on laboratory methods by 11 others: U.S. Geological Survey Professional Paper 954-A, 39 p.

1976b, Sampling designs for geochemical surveys-syllabus for a short course: U.S. Geological Survey Open-file Report $76-772,138 \mathrm{p}$.

Oertel, A. C., 1959, Estimation of the trace element status of large areas of soil: Australian Journal of Agricultural Research, v. 10, p. $58-70$

Omodt, H. W., Johnsgard, G. A., Patterson, D. D., and Olson, O. P., 1968, The major soils of North Dakota: North Dakota State University Agricultural Experiment Station Bulletin 472,60 p.

Protz, R., Presant, E. W., and Arnold, R. W., 1968, Establishment of the modal profile and measurement of variability within a soil landform unit: Canadian Journal of Soil Science, v. 48, p. 7-19.

Reynolds, S. G., 1975, Soil Property variability in slope studies suggested sampling schemes and typical required samples sizes: Zeitschrift für Geomorphologie, v. 19, no. 2, p. 191-208.

Southard, A. R., 1969, Soils of Montana: Montana State University Agriculture Experiment Station Bulletin 621, 42 p.

Tidball, R. R., 1975, Sampling requirements for mapping soil geochemistry in the Powder River Basin, in U.S. Geological Sur- vey, Geochemical survey of the western coal regions, 2nd annual progress report, July 1975: U.S. Geological Survey Open-file Report $75-436$, p. $20-28$.

1976, Chemical variation of soils in Missouri associated with selected levels of the soil classification system: U.S. Geological Survey Professional Paper 954-B, 16 p.

Tidball, R. R., and Ebens, R. J., 1976, Regional geochemical baselines in soils of the Powder River Basin, Montana-Wyoming, in Laudon, R. B., ed., Geology and energy resources of the Powder River: Wyoming Geological Association Guidebook, 28th annual field conference, p. 299-310.

Tourtelot, H. A., and Miesch, A. T., 1975, Sampling designs in environmental geochemistry: Geological Society of America Special Paper no. 155, p. 107-118.

U.S. Geological Survey, 1974, Stripping coal deposits of the northern Great Plains, Montana, Wyoming, North Dakota, and South Dakota: U.S. Geological Survey Miscellaneous Field Studies Map MF-590, scale 1:1,000,000.

, 1975, Geochemical survey of the western coal regions, 2nd annual progress report, July 1975: U.S. Geological Survey Openfile Report 75-436, $132 \mathrm{p}$.

1976 , Geochemical survey of the western energy regions, $3 \mathrm{rd}$ annual progress report, July 1976: U.S. Geological Survey Openfile Report 76-729, 252 p.

VanTrump, George, Jr., and Miesch, A. T., 1977, The U.S. Geological Survey RASS-STATPAC system for management and statistical reduction of geochemical data: Computers and Geoscience, v. 3, no. 3, p. 475-488.

Walker,P.H., Hall, G. F., and Protz, R., 1968, Soil trends and variability across selected landscapes in Iowa: Soil Science Society of America Proceedings, v. 32, p. 97-101.

Webster, R., and Butler, B. E., 1976, Soil classification and survey studies at Ginninderra: Australian Journal of Soil Research, v. 14, p. 1-24.

Westin, F. C., Puhr, L. F., and Buntley, G. J., 1967, Soils of South Dakota rev. ed.: South Dakota State University Agricultural Experiment Station Soil Survey Series 3,32 p.

Whitaker, S. H., and Pearson, D. E., 1972, Geological map of Saskatchewan: Saskatchewan Department of Mineral Resources, Geologic Science Branch-Saskatchewan Research Council, Geologic Division, scale 1:1,267,200.

Wilding, L. P., Jones, R. B., and Schafer, G. M., 1965, Variation of soil morphological properties within Miami, Celina, and Crosby mapping units in west-central Ohio: Soil Science Society of America Proceedings, v. 29, p. 711-717. 


\section{Regional Soil Chemistry in the Bighorn and Wind River Basins, Wyoming and Montana}

By R. C. SEVERSON

GEOCHEMICAL SURVEY OF THE WESTERN ENERGY REGIONS

GEOLOGICAL SURVEY PROFESSIONAL PAPER $1134-$ B

Baseline values for 38 elements characterize

the composition of soils

overlying major geologic units in each Basin

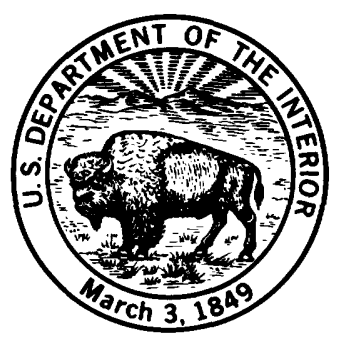




\section{UNITED STATES DEPARTMENT OF THE INTERIOR}

CECIL D. ANDRUS, Secretary

\section{GEOLOGICAL SURVEY}

H. William Menard, Director

Library of Congress Cataloging in Publication Data

Severson, Ronald Charles, 1945-

Regional Soil Chemistry in the Bighorn and Wind River Basins, Wyoming and Montana

(Geochemical Survey of the Western Energy Regions) (Geological Survey Professional Paper 1134-B)

Bibliography : p. B'

1. Soil chemistry-Bighorn Basin, Mont. and Wyo. 2. Soil chemistry-Wyoming-Wind River Basin.

3. Soils-Bighorn Basin, Mont. and Wyo.-Composition. 4. Soils-Wyoming-Wind River Basin-Composition.

5. Bighorn Basin, Mont, and Wyo. 6. Wind River Basin, Wyo. I. Title. II. Series. III. Series: United States Geological Survey Professional Paper 1134-B

S599.W8S48 631.4'1'09787

$79-607781$

For sale by the Superintendent of Documents, U.S. Government Printing Office

Washington, D. C. 20402

Stock Number 024-001 -03230-9 


\section{CONTENTS}

\begin{tabular}{|c|c|}
\hline Page & $\mathrm{Pa}$ \\
\hline act - & 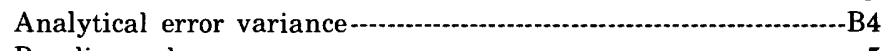 \\
\hline ntroduction -........ 1 & 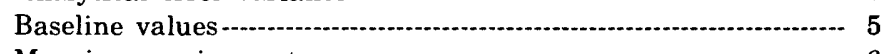 \\
\hline tudy area-....-..-. & 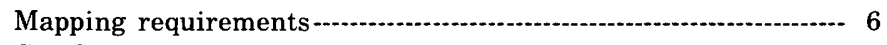 \\
\hline npling design-- & \\
\hline & \\
\hline
\end{tabular}

\section{ILLUSTRATIONS}

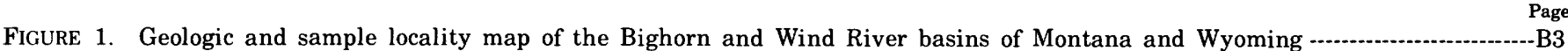

2. Diagrammatic representation of a barbell design with sampling localities shown as $X$ 's

\section{TABLES}

Tage

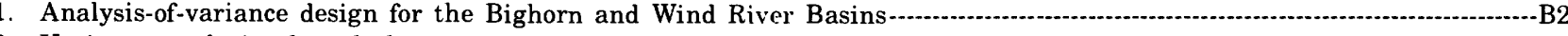

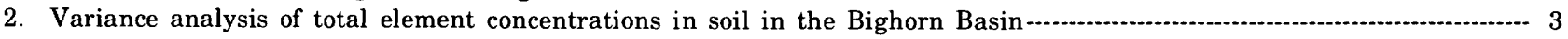

3. Variance analysis of total element concentration in soil in the Wind River Basin ................................................... 4

4. Statistical summary for elements that lack regional variation in soils of the Bighorn Basin -..................................... 4

5. Statistical summary for elements that lack regional variation in soils of the Wind River Basin-........................... 5

6. Statistical summary for the element having regional variation in soils that overlie the three major geologic units in the Bighorn Basin

7. Statistical summary for elements having regional variation in soils that overlie the three major geologic units in the Wind River Basin

8. Average concentrations of elements in soils and surficial materials in the Bighorn, Wind River, and Powder River Basins and in the Western United States

9. Minimum number of samples needed in a 10-km square to map total element concentrations in soils of the Bighorn and Wind River Basins at the 80 percent confidence level 



\title{
REGIONAL SOIL CHEMISTRY IN THE BIGHORN AND WIND RIVER BASINS, WYOMING AND MONTANA
}

\author{
By R. C. SEverson
}

\section{ABSTRACT}

A reconnaissance study of total concentrations of 38 elements in samples of soils ( $0-40 \mathrm{~cm}$ deep, composite) from the Bighorn and Wind River Basins of Montana and Wyoming indicates that the geographic variation for most elements occurs locally ( $5 \mathrm{~km}$ or less). However, in the Bighorn Basin, $\mathrm{Zn}$ exhibits significant regional variation (between geologic units); and in the Wind River Basin, $\mathrm{Al}, \mathrm{Cr}, \mathrm{K}, \mathrm{Mn}, \mathrm{Mo}, \mathrm{Ni}, \mathrm{U}$, and $V$ exhibit similar variation. For the remaining elements, the lack of regional variation suggests that a single summary statistic can be used to estimate a baseline value that reflects the range in concentration to be expected in samples of soils in each basin. The concentrations of most of these elements in both basins are not much different from those measured independently in the Powder River Basin of Wyoming or in the Western United States. In addition, data from an analysis of variance provide an estimate of the number of random samples within an area of specified size ( $10 \mathrm{~km}$ square, approximately a township) that are needed to prepare a reliable map of total element concentration in soils for each of the elements in each of the basins.

\section{INTRODUCTION}

This reconnaissance study provides data on spatial variation in total element concentrations in soil in the Bighorn and Wind River Basins. The data provide chemical baseline values for the two areas. The baseline values enable the monitoring of any changes that might result from disturbances of the geochemical environment by activities such as energy development. The baseline value for each element accounts for the natural chemical variability of soils and may be defined as the 95-percent range in concentration to be expected in samples of soils in these basins. In addition, differences between cell averages may be used to determine the feasibility of mapping regional variation in concentrations of elements in soils at a mapping interval greater than $10 \mathrm{~km}$.

\section{STUDY AREA}

The Bighorn and Wind River Basins are structural basins formed in late Cretaceous and early Tertiary time (Keefer, 1965). During Eocene time, the basins became progressively filled; by Oligocene time, the bordering mountain ranges were largely buried; and by Pliocene time, only the highest parts of the ranges stood above a broad depositional plain (Love, 1970).

In early Eocene time the basin fill was obtained from erosion of the surrounding mountains made up of Precambrian, Paleozoic, and Mesozoic rocks. The western border of the Bighorn Basin is east of the Absaroka Range at the border of the erosional scarp of the Absaroka volcanic plateau; these volcanic rocks of Eocene and younger ages contributed debris for the later filling of the basin but contributed little to the earlier deposits. The eastern border of the Wind River Basin is the Powder River lineament, a sharply folded belt of Cretaceous and Paleozoic rocks that contributed little debris to the basin fill. The Granite Mountains along the southern margin of the Wind River Basin mark the structural boundary of the basin but are buried by strata of Miocene and Pliocene age; this region is included in this study in order to obtain data on the general composition of these younger rocks, which are markedly different from the lower Eocene rocks that make up the oldest levels of the basin fill. Distribution of rock units is taken from Andrews, Pierce, and Eargle (1947) for the Bighorn Basin and from Whitcomb and Lowry (1968) for the Wind River Basin.

Coal occurs in rocks of Cretaceous and Paleocene age in both basins. Although small amounts of coal have been mined in each basin in the past (Keefer, 1965), it seems unlikely that energy resource development in the Bighorn and Wind River Basins (except for uranium in the Wind River Basin) will be comparable to that foreseen for the Powder River Basin (U.S. Bureau of Land Management, written commun., 1973).

Data on the composition of soils of the two basins are useful for comparison with each other and with data from the Powder River Basin. The data are also used in establishing a chemical background against which any changes can be measured in regions where development has taken place. 


\section{SAMPLING DESIGN}

Chemical variation between geologic units within basins, and within geologic units across different distances, was estimated from an unbalanced, nested analysis-of-variance design. The analysis-of-variance design used in this study is shown in table 1. Sampling sites were randomly located using a barbell design within each of the primary geologic units within each of the basins (fig. 1).

The major axis of the barbell was $25 \mathrm{~km}$ long, and the sequentially smaller axes of each barbell were 10,5 , and $1 \mathrm{~km}$ long, respectively. All axes were oriented by selecting a compass direction at random. A barbell design is shown in figure 2 . In each of the six barbells, 12 samples were collected for a total of 72 samples. Also, for each set of 12 samples, 4 samples were randomly selected to be split and analyzed twice, yielding a total of 24 samples split and analyzed in duplicate. These sample splits represent the analytical-error level of the sampling design (tables 2 and 3 ).

Soils on the geologic unit of Paleocene age (Fort Union Formation) were sampled only in the Bighorn Basin, and those on the geologic units of Miocene and Pliocene age (Moonstone and Arikaree Formations, respectively) were sampled only in the Wind River Basin. Soils on the geologic units of Eocene age (Wind River and Indian Meadows Formations in the Wind River Basin and Willwood Formation in the Bighorn Basin) and on deposits of Quaternary age were sampled in both basins. Soils on the pre-Tertiary geologic unit were not sampled.

\section{SAMPLES AND ANALYSES}

The material collected at each sample location consisted of a composite sample of soil, excluding coarse fragments, from 0 to $40 \mathrm{~cm}$ in depth. In the laboratory, all samples were dried under forced air at ambient temperature. The samples were disaggregated using a mechanical, ceramic mortar and pestle, and the fraction passing a 10 -mesh $(2-\mathrm{mm})$ sieve was saved. The saved fraction was further ground to pass a 100 -mesh $(150 \mu \mathrm{m})$ sieve; this material was used for all chemical analyses. The 96 total samples (72 samples plus 24 splits) were analyzed in a random sequence, so that any systematic errors in sample preparation and analysis would be effectively converted to random errors and not bias the interpretation of results.

Analyses for some elements present in trace quantities commonly result in censored data, because part of the normal range of concentrations is smaller than the lower limit of determination for the analytical method. Because statistical tests require a complete numeric data set, censored values were replaced by arbitrary concentrations equal to 0.7 times the value that represents a lower limit of determination for the analytical method. This replacement is justified by the fact that

TABLE 1.-Analysis-of-variance design for the Bighorn and Wind River Basins

[Each $s,{ }^{2}$ is an estimate of the variation associated with the sources of variation: for example, $s_{u}{ }^{2}$ is variation between geologic units and $s_{u}{ }^{2}$ is the variation between duplicate analyses; .., no F-ratio exists]

\begin{tabular}{|c|c|c|c|c|c|c|}
\hline Source of variation & $\begin{array}{c}\text { Degrees } \\
\text { of } \\
\text { freedom }\end{array}$ & Mean square estimates & F-ratio & & $\begin{array}{l}\text { Variance } \\
\text { component }\end{array}$ & \\
\hline Between geologic units & 2 & $M S_{1}=s_{a}^{2}+1.5 s_{1}^{2}+2.3 s_{5}^{2}+4.1 s_{10}^{2}+8.1 s_{25}^{2}+16 s_{u}^{2}$ & $\frac{\mathrm{MS}_{1}}{\mathrm{MS}_{2}}$ & $s_{u}^{2}=$ & $\frac{\mathrm{MS}_{1}-\mathrm{MS}_{2}}{16}$ & $\cong \sigma_{u}^{2}$ \\
\hline $10-25 \mathrm{~km}$ distance----- & 3 & $M_{2}=s_{a}^{2}+1.5 s_{1}^{2}+2.3 s_{5}^{2}+4.0 s_{10}^{2}+7.9 s_{15}^{2}$ & $\frac{\mathrm{MS}_{2}}{\mathrm{MS}_{3}}$ & $\mathrm{~s}_{25}^{2}=$ & $\frac{\mathrm{MS}_{2}-\mathrm{MS}_{3}}{7.9}$ & $\cong \sigma_{25}^{2}$ \\
\hline $5-10 \mathrm{~km}$ distance-- & 6 & $\mathrm{MS}_{3}=\mathrm{s}_{\mathrm{a}}^{2}+1.4 \mathrm{~s}_{1}^{2}+2.3 \mathrm{~s}_{5}^{2}+4.0 \mathrm{~s}_{10}^{2}$ & $\frac{\mathrm{MS}_{3}}{\mathrm{MS}_{4}}$ & $\mathrm{~s}_{10}^{2}=$ & $\frac{\mathrm{MS}_{3}-\mathrm{MS}_{4}}{4.0}$ & $\cong \sigma_{10}^{2}$ \\
\hline $1-5 \mathrm{~km}$ distance------- & 12 & $\mathrm{MS}_{4}=\mathrm{s}_{\mathrm{a}}^{2}+1.3 \mathrm{~s}_{1}^{2}+1.7 \mathrm{~s}_{5}^{2}$ & $\frac{\mathrm{MS}_{4}}{\mathrm{MS}_{5}}$ & $s_{5}^{2}=$ & $\frac{\mathrm{MS}_{4}-\mathrm{MS}_{5}}{1.7}$ & $\cong \sigma_{5}^{2}$ \\
\hline $0-1 \mathrm{~km}$ distance---- & 12 & $\mathrm{MS}_{5}=\mathrm{s}_{\mathrm{a}}^{2}+1.2 \mathrm{~s}_{1}^{2}$ & $\frac{\mathrm{MS}_{5}}{\mathrm{MS}_{6}}$ & $s_{1}^{2}=$ & $\frac{\mathrm{MS}_{5}-\mathrm{MS}_{6}}{1.2}$ & $\cong \sigma_{1}^{2}$ \\
\hline Between analyses------ & 12 & $M S_{6}=s_{a}^{2}$ & --- & & $s_{a}^{2} \cong \sigma_{a}^{2}$ & \\
\hline
\end{tabular}




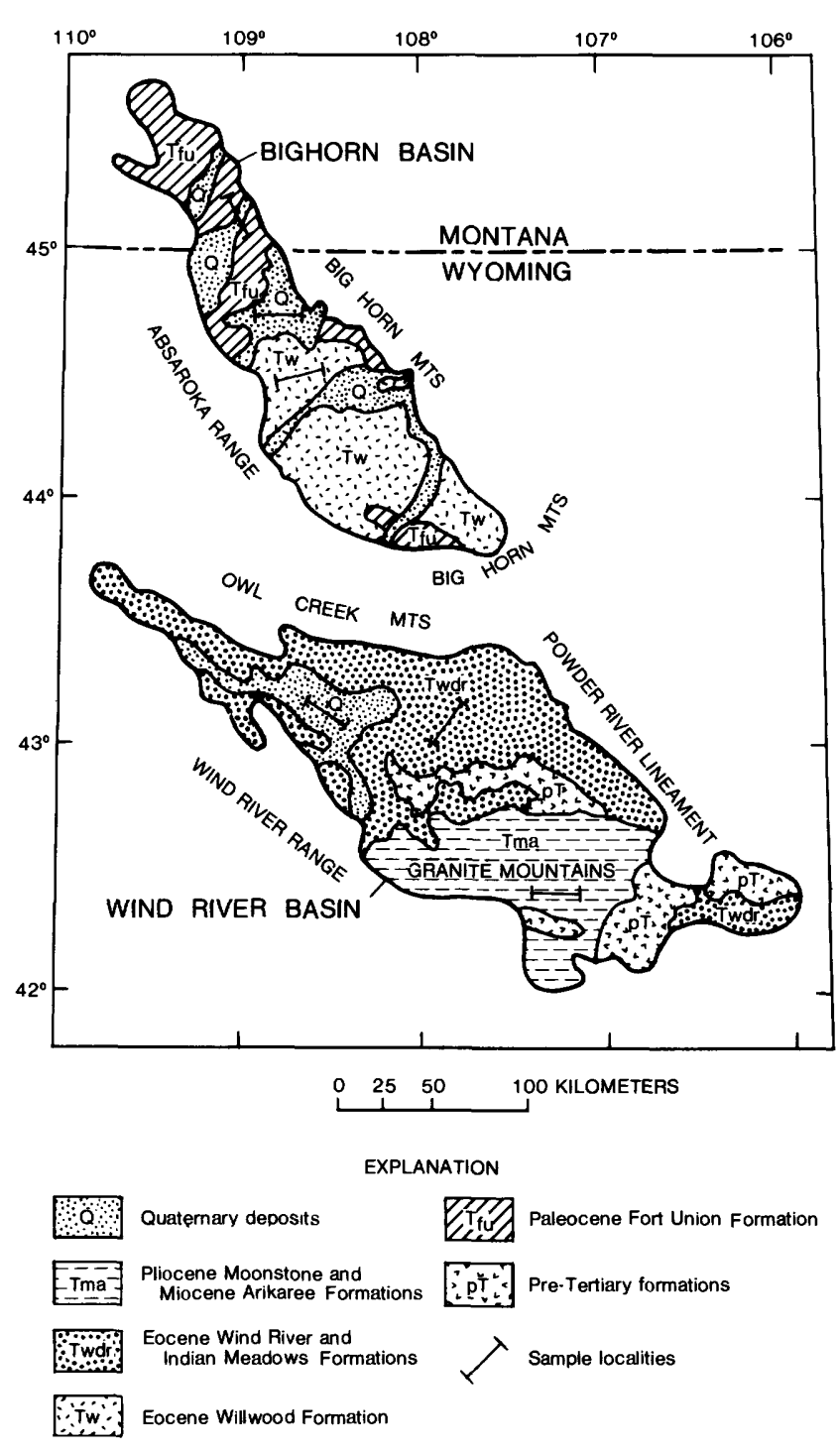

FiguRE 1.-Geologic and sample locality map of the Bighorn and Wind River Basins of Montana and Wyoming. Geology modified from Andrews, Pierce, and Eargle (1947), and Whitcomb and Lowry (1968).

the small number of replaced values (affecting samples with detection ratios of $<1: 1$ in tables $4-7$ ) does not significantly alter the results of the statistical tests. However, when one-quarter or more of the analyses for a particular element were censored, the data for that element were discarded and, therefore, not reported in this study. The highly censored elements were $\mathrm{Ag}, \mathrm{Au}, \mathrm{Bi}$, $\mathrm{Br}, \mathrm{Cd}, \mathrm{Cl}, \mathrm{Cs}, \mathrm{Dy}, \mathrm{Er}, \mathrm{F}, \mathrm{Gd}, \mathrm{Hf}, \mathrm{Ho}$, I, In, Ir, Nd, Os, P, Pd, $\mathrm{Pr}, \mathrm{Pt}, \mathrm{Re}, \mathrm{Rh}, \mathrm{Ru}, \mathrm{S}, \mathrm{Se}, \mathrm{Sm}, \mathrm{Ta}, \mathrm{Tb}, \mathrm{Te}, \mathrm{Tl}, \mathrm{Tm}$, and W.

Elements occurring in trace quantities in natural materials commonly tend to exhibit positively skewed frequency distributions. Therefore, a logarithmic transformation of the data prior to statistical analysis was used to improve the estimate of the most probable concentration of an element in natural materials. The fre-

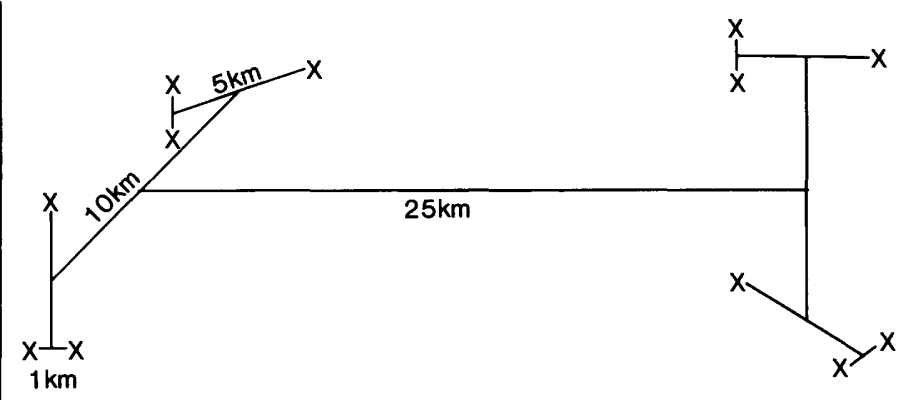

FIGURE 2.-Diagrammatic representation of a barbell design with sample localities shown as $\times$ 's.

TABLE 2.-Variance analysis of total element concentration in soil in the Bighorn Basin

[The sample consisted of a composite of soil from a 0- to 40-cm depth; total variance is computed on logarithmically transformed data; ${ }^{*}$. variance component is significantly different from zero at the 0.05 probability level; estimates based on analyses of 48 samples]

\begin{tabular}{|c|c|c|c|c|c|c|c|}
\hline \multirow[b]{2}{*}{ Element } & \multirow{2}{*}{$\begin{array}{c}\text { Total } \\
\text { variance }\end{array}$} & \multicolumn{6}{|c|}{ Percent of total variance } \\
\hline & & $\begin{array}{l}\text { Bet ween } \\
\text { geologic } \\
\text { unit s }\end{array}$ & $10-25 \mathrm{~km}$ & $5-10 \mathrm{~km}$ & $1-5 \mathrm{~km}$ & $0-1 \mathrm{~km}$ & $\begin{array}{l}\text { Analyt ical } \\
\text { error }\end{array}$ \\
\hline A1----- & 0.0205 & 10.2 & 0 & 0 & $51.2 *$ & $31.1^{*}$ & 7.5 \\
\hline & .1143 & 0 & $14.1 *$ & 0 & & 26.3 & 59.6 \\
\hline B------ & .0189 & 5.9 & 0 & 0 & 21.3 & $56.8^{*}$ & 16.1 \\
\hline Ba---- & .0335 & 10.6 & 2.0 & 6.3 & 0 & 0 & 81.1 \\
\hline Be----- & .0282 & 0 & 5.3 & 0 & $51.4^{*}$ & 13.8 & 29.5 \\
\hline c----- & .0826 & 0 & $58.9 *$ & 0 & $24.2^{*}$ & $11.2 *$ & 5.6 \\
\hline Ca----- & .0185 & 0 & $27.1 *$ & 0 & 27.7 & $45.1 *$ & 0.2 \\
\hline Ce----- & .0314 & 0 & $27.9 *$ & 0 & 0 & 17.7 & 54.4 \\
\hline Co----- & .0183 & 16.5 & 0 & 10.1 & 34.6 & 20.8 & 18.0 \\
\hline Cr---.- & .0434 & 5.4 & 0 & 0 & $77.7 *$ & 8.8 & 8.2 \\
\hline Cu----- & .0610 & 8.1 & 0 & 0 & $56.1 *$ & 16.0 & 19.8 \\
\hline Fe----- & .0239 & 23.0 & 0 & 8.8 & $46.3 *$ & $17.9 *$ & 4.0 \\
\hline Ga----- & .0365 & 11.7 & 0 & 0 & 42.3 & $29.7 *$ & 16.3 \\
\hline Ge----- & .2257 & 0 & 0 & 6.6 & 14.7 & & 78.7 \\
\hline Hg----- & .0210 & 5.1 & 0 & 17.5 & 0 & $57.1^{*}$ & 20.3 \\
\hline K------ & .0081 & 0 & 7.7 & 0 & 39.0 & $42.2^{*}$ & 11.1 \\
\hline La---- & .0096 & 0 & 0 & 0 & 9.2 & 50.8 & 40.0 \\
\hline Li-C- & .0189 & 10.5 & 0 & 0 & $49.9 *$ & $29.4^{*}$ & 10.3 \\
\hline Mg----- & .0120 & 10.0 & 0 & 32.2 & 10.4 & $46.4^{*}$ & 0.8 \\
\hline Mn---- & .0277 & 0 & 25.3 & 0 & 22.2 & $44.8^{*}$ & 7.7 \\
\hline Mo----- & .0396 & 7.6 & 0 & 0 & 43.2 & 26.9 & 22.2 \\
\hline Na--_-- & .0435 & 42.2 & 17.4 & 7.3 & & $32.7 *$ & 0.3 \\
\hline Nb--- & .0230 & 2.5 & 4.2 & 0 & 8.3 & & 85.0 \\
\hline Ni----- & .0229 & 12.7 & 0 & 0 & 41.5 & $34.4^{*}$ & 11.4 \\
\hline Pb----- & .0337 & 3.6 & 0 & 0 & 0 & 46.5 & 49.9 \\
\hline Rb------ & .0223 & 0 & 15.2 & 0 & $44.0 *$ & 0 & 40.9 \\
\hline Sc--.-- & .0452 & 3.6 & 11.9 & 0 & 40.2 & $31.4 *$ & 13.0 \\
\hline Si----- & .0022 & 10.3 & 0 & 31.0 & 15.3 & $28.6 *$ & $\begin{array}{r}5.8 \\
75.7\end{array}$ \\
\hline Sn----- & .1678 & 0 & 0 & 20.9 & 3.4 & 0 & 75.7 \\
\hline Sr---- & .0246 & 11.1 & 17.2 & 14.7 & 13.9 & $38.4^{*}$ & 4.8 \\
\hline Th----- & .0161 & 0 & 2.3 & 0 & 27.9 & $51.0^{*}$ & 18.8 \\
\hline Ti---- & .0083 & 0.7 & 0 & 0 & 26.8 & $67.6 *$ & 5.0 \\
\hline U------ & .0101 & 0 & 0 & 10.6 & 20.7 & $65.1 *$ & 3.6 \\
\hline v------ & .0253 & 0 & 2.2 & 0 & $61.6 *$ & $30.7^{*}$ & 5.5 \\
\hline Y------ & .0165 & 0 & 0 & 0 & $58.5 *$ & 19.8 & 21.7 \\
\hline Yb------ & .0187 & & 0 & 3.1 & $65.1 *$ & 20.5 & 11.3 \\
\hline $\mathrm{Zn}-$ & .0212 & $15.3 *$ & 0 & 1.5 & $46.4 *$ & $26.6 *$ & 10.3 \\
\hline $2 \mathrm{r}-\cdots$ & .0253 & 0 & 0 & 32.4 & 0 & 17.7 & 48.1 \\
\hline
\end{tabular}

quency distribution of the log-transformed data more nearly resembles a normal distribution, one of the basic assumptions for the analysis of variance.

Chemical analyses were done in the U.S. Geological Survey analytical laboratories in Denver, Colorado. 
TABLE 3-Variance analysis of total element concentration in soil in the Wind River Basin

[The sample consisted of a composite of soil from a 0 - to $40-\mathrm{cm}$ depth; total variance is computed on logarithmically transformed data; ${ }^{*}$, variance component is significantly different from zero at the 0.05 probability level; estimates based on analyses of 48 samples]

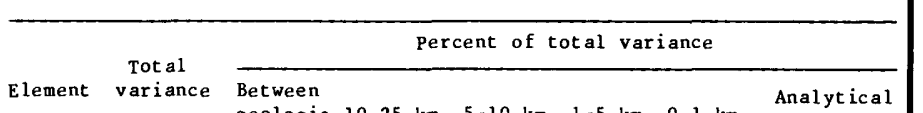

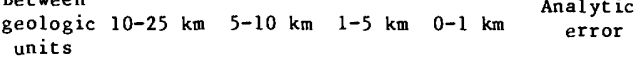

\begin{tabular}{|c|c|c|c|c|c|c|c|}
\hline $\mathrm{Al}--$ & 0.0069 & 33.1 * & 0 & 2.8 & 5.9 & $43.2 *$ & 15.0 \\
\hline As----- & .1012 & 3.2 & 0.4 & 0 & 62.7 * & 13.1 & 20.6 \\
\hline B-- - - & .0272 & 14.0 & 0 & 0 & 27.1 & $44.7 *$ & 14.2 \\
\hline Ba-- - & .0082 & 0 & 0 & 4.9 & 17.9 & 0 & 77.2 \\
\hline Be----- & .0184 & 11.4 & 0 & 24.4 & 21.7 & 0 & 42.5 \\
\hline C------ & .0494 & 5.4 & 0 & 20.8 & 13.7 & $50.9 *$ & 9.2 \\
\hline Ca----- & .0987 & 11.8 & 0 & 21.6 & $37.6 *$ & $28.8 *$ & 0.3 \\
\hline $\mathrm{Ce}---$ & .1290 & 1.0 & 1.3 & 0.2 & 0 & 0 & 97.5 \\
\hline Co----- & .0333 & 15.2 & 0 & 8.4 & 34.9 & $28.9 *$ & 12.6 \\
\hline Cr---- & .0566 & $65.4 *$ & 0 & 0 & 5.9 & $25.2 *$ & 3.5 \\
\hline Cur--- & .0731 & 11.7 & 0 & 0 & 22.6 & $38.5 *$ & 27.2 \\
\hline $\mathrm{Fe}---$ & .0228 & 7.9 & 0 & 29.4 & 0 & $59.2 *$ & 3.5 \\
\hline Ga----- & .0229 & 12.4 & 6.2 & 0 & $51.0 *$ & 9.7 & 20.7 \\
\hline Ge------ & .1575 & 0 & 0 & 5.4 & 15.9 & 14.0 & 64.7 \\
\hline Hg----- & .0267 & 0 & 23.6 & 0 & 10.2 & 23.4 & 42.8 \\
\hline K------- & .0042 & $12.0 *$ & 0 & 0 & $67.6 *$ & 5.7 & 14.7 \\
\hline La-- & .1116 & 0.6 & 1.4 & 4.8 & 0 & 0 & 93.2 \\
\hline Li-C.- & .0359 & 3.4 & 0 & 14.7 & 21.8 & $57.6 *$ & 3.1 \\
\hline Mg----- & .0528 & 37.1 & 0 & 15.1 & 0 & $46.9 *$ & 1.0 \\
\hline Mn----- & .0305 & $26.3 *$ & 0 & 0 & 34.9 & $26.2 *$ & 12.6 \\
\hline Mo------ & .0441 & $22.1 *$ & 0 & 0 & 16.9 & $42.4 *$ & 18.6 \\
\hline $\mathrm{Na}--$ & .0115 & 0 & 0 & 16.4 & $69.8 *$ & $12.8 *$ & 1.0 \\
\hline Nb- & .0340 & 0.2 & 0 & 0 & 33.9 & 0 & 65.9 \\
\hline $\mathrm{Ni}-$ & .0492 & $47.9 *$ & 0 & 0 & 14.9 & $29.2 *$ & 8.1 \\
\hline $\mathrm{Pb}----$ & .0395 & 0 & 0 & 0 & 8.2 & 0 & 91.8 \\
\hline Rb------ & .0240 & $15.6 *$ & 0 & 6.8 & 0 & 14.0 & 63.6 \\
\hline Sc--- & .0342 & 16.6 & 0 & 22.3 & 14.3 & 22.3 & 24.5 \\
\hline Si----- & .0011 & 0 & 2.3 & 9.5 & $53.7 *$ & 14.0 & 20.6 \\
\hline Sn-_-..- & .2108 & 0 & 0 & 0 & 13.0 & 16.7 & 70.3 \\
\hline $\mathrm{Sr}=$ & .0258 & 2.5 & 32.6 & $31.4 *$ & 7.5 & 14.7 & 11.4 \\
\hline Th----- & .0238 & 33.8 & 12.2 & 0 & $30.1 *$ & $16.0^{*}$ & 7.9 \\
\hline Ti-- - & .0098 & 12.6 & 0 & 25.9 & 13.3 & $40.4 *$ & 7.8 \\
\hline U- & .0097 & $15.6 *$ & 0 & 0 & 0.6 & 79.7 * & 4.2 \\
\hline V------ & .0195 & 10.6 * & 0 & 0 & 18.9 & $59.5 *$ & 11.0 \\
\hline Y------ & .0410 & 0 & 4.4 & 0 & 11.8 & 0 & 83.9 \\
\hline Yb----- & .0639 & 0 & 5.1 & 0 & 11.7 & 0 & 83.2 \\
\hline Zn---.-- & .0163 & 24.0 & 0 & 2.8 & 10.4 & $55.2 *$ & 7.5 \\
\hline $\mathrm{zr}$ & .0247 & 9.4 & 0 & 0 & 0 & 0 & 90.6 \\
\hline
\end{tabular}

Sample preparation and analyses were performed by James S. Baker, A. J. Bartel, E. L. Brandt, J. G. Crock, I. C. Frost, Johnnie M. Gardner, Patricia Gayle Guest, Raymond G. Havens, J. P. Hemming, Kathryn E. Horan, Claude Huffman, Jr., J. O. Johnson, R. J. Knight, R. M. Lemert, R. E. McGregor, Violet M. Merritt, H. T. Millard, Jr., Wayne Mountjoy, G. O. Riddle, V. E. Shaw, M. W. Solt, J. A. Thomas, Michele L. Tuttle, R. E. Van Loenen, R. J. Vinnola, J. S. Wahlberg, and R. J. White. The analytical methods are described in a previously published report (U.S. Geological Survey, 1975).

All computations were done on a HoneywellMULTICS computer using statistical programs in the U.S. Geological Survey's STATPAC Library (Van Trump and Miesch, 1977).
TABLE 4.-Statistical summary for elements that lack regional variation in soils of the Bighorn Basin

[Detection ratio, number of samples in which the element was found in measurable concentrations relative to the number of samples analyzed; *, elements measured in percent; other elements measured in parts per million]

\begin{tabular}{|c|c|c|c|c|c|c|}
\hline Element & $\begin{array}{c}\text { Geometric } \\
\text { mean }\end{array}$ & $\begin{array}{l}\text { Geometric } \\
\text { deviation }\end{array}$ & $\begin{array}{l}\text { Geometric } \\
\text { error }\end{array}$ & $\begin{array}{r}\text { Bas } \\
\text { va }\end{array}$ & $\begin{array}{l}\text { seline } \\
\text { alue }\end{array}$ & $\begin{array}{l}\text { Detection } \\
\text { ratio }\end{array}$ \\
\hline $\mathrm{Al} *----$ & 4.0 & 1.32 & 1.09 & 2.4 & $-\quad 4.8$ & $36: 36$ \\
\hline B- - - & 50 & 1.33 & 1.14 & 30 & -83 & $36: 36$ \\
\hline Be- - & 2.0 & 1.40 & 1.23 & 1.2 & -3.4 & $36: 36$ \\
\hline C*-- - & 1.5 & 1.72 & 1.17 & 0.53 & -4.2 & $36: 36$ \\
\hline $\mathrm{Ca}^{*}---$ & 3.0 & 1.78 & 1.03 & 0.95 & -9.5 & $36: 36$ \\
\hline $\mathrm{Co}_{0}-\cdots$ & 6.3 & 1.33 & 1.14 & 3.8 & -10 & $36: 36$ \\
\hline Cr $-\cdots$ & 59 & 1.55 & 1.15 & 26 & -135 & $36: 36$ \\
\hline $\mathrm{Cu}----$ & 20 & 1.65 & 1.29 & 8.4 & -47 & $36: 36$ \\
\hline $\mathrm{Fe}^{\star}-$ & 1.8 & 1.38 & 1.07 & 0.96 & $-\quad 3.4$ & $36: 36$ \\
\hline $\mathrm{Ga}----$ & 11 & 1.47 & 1.19 & 5.5 & -22 & $36: 36$ \\
\hline $\mathrm{Hg}=---$ & 0.026 & 1.33 & 1.16 & 0.016 & $5=0.042$ & $36: 36$ \\
\hline$K * \cdots---$ & 1.5 & 1.19 & 1.07 & 1.1 & -2.1 & $36: 36$ \\
\hline La- - - & 36 & 1.20 & 1.15 & 28 & -45 & $36: 36$ \\
\hline Li一- & 18 & 1.31 & 1.11 & 11 & -30 & $36: 36$ \\
\hline Mg*---- & 0.86 & 1.41 & 1.04 & 0.4 & -1.7 & $36: 36$ \\
\hline Mn----- & 400 & 1.38 & 1.11 & 220 & -740 & $36: 36$ \\
\hline Mo---- & 4.8 & 1.47 & 1.24 & 2.5 & $-\quad 9.1$ & $35: 36$ \\
\hline $\mathrm{Na*}-$ & 0.53 & 1.53 & 1.03 & 0.23 & -1.2 & $36: 36$ \\
\hline $\mathrm{Ni}--$ & 22 & 1.37 & 1.13 & 12 & -39 & $36: 36$ \\
\hline $\mathrm{Pb}-----$ & 8.6 & 1.44 & 1.35 & 5.7 & -13 & $36: 36$ \\
\hline $\mathrm{Rb}=---$ & 55 & 1.32 & 1.25 & 40 & -77 & $36: 36$ \\
\hline Sc- & 5.9 & 1.59 & 1.19 & 2.5 & -14 & $32: 36$ \\
\hline $\mathrm{Si}_{i * \ldots-}$ & 32 & 1.10 & 1.03 & 27 & -38 & $36: 36$ \\
\hline Sr- - & 230 & 1.39 & 1.08 & 120 & -440 & $36: 36$ \\
\hline Th- - - & 8.5 & 1.27 & 1.13 & 5.6 & -13 & $36: 36$ \\
\hline Ti*--- & 0.26 & 1.22 & 1.05 & 0.18 & -0.38 & $36: 36$ \\
\hline $\mathrm{U}-$ & 2.7 & 1.25 & 1.05 & 1.7 & -4.2 & $36: 36$ \\
\hline V- & 68 & 1.34 & 1.09 & 39 & -120 & $36: 36$ \\
\hline $\mathrm{Y}--$ & 20 & 1.28 & 1.15 & 13 & -30 & $36: 36$ \\
\hline $\mathrm{Yb}--$ & 2.7 & 1.33 & 1.11 & 1.6 & -4.6 & $36: 36$ \\
\hline $\mathrm{Zr}-\cdots$ & 320 & 1.35 & 1.29 & 230 & -440 & $36: 36$ \\
\hline
\end{tabular}

$1_{\text {Expected }}$ 95-percent range.

\section{ANALYTICAL ERROR VARIANCE}

The distributions of variance components for 38 elements in soils from the two basins are shown in tables 2 and 3. For 6 elements in the Bighorn Basin and 11 elements in the Wind River Basin, the variance due to analytical error accounts for more than 50 percent of the total observed variation. This error is judged to be excessive and, therefore, any interpretation of the data for these elements must be made with extreme caution.

Excessive analytical errors result in duplicate samples being reported as having widely different concentrations. The analytical procedure, rather than splitting errors or particle effect, is probably the best explanation for this excessive error. If splitting errors or particle effect were responsible, then a larger number of elements would exhibit excessive error. Concentrations of all elements, except $\mathrm{Rb}$, that exhibit excessive analytical error were determined by multi-element emission spectrography or X-ray fluorescence. Atomic ab- 
TABLE 5.-Statistical summary for elements that lack regional variation in soils of the Wind River Basin

[Detection ratio, number of samples in which the element was found in measurable concentrations relative to the number of samples analyzed; *, elements measured in percent; other elements measured in parts per million]

\begin{tabular}{|c|c|c|c|c|c|c|}
\hline Element & $\begin{array}{c}\text { Geometric } \\
\text { mean }\end{array}$ & $\begin{array}{l}\text { Geometric } \\
\text { deviation }\end{array}$ & $\begin{array}{c}\text { Geometric } \\
\text { error }\end{array}$ & $\begin{array}{r}\text { Bas } \\
\text { va }\end{array}$ & $\begin{array}{l}\text { eline } \\
\text { lue }\end{array}$ & $\begin{array}{l}\text { Detection } \\
\text { ratio }\end{array}$ \\
\hline As- --- & 3.6 & 1.90 & 1.39 & 1.2 & -10.8 & $36: 36$ \\
\hline B- $\cdots$ & 28 & 1.38 & 1.15 & 16 & -50 & $36: 36$ \\
\hline $\mathrm{Be}--\cdots$ & 2.4 & 1.29 & 1.23 & 1.8 & $-\quad 3.2$ & $36: 36$ \\
\hline$C *-----$ & 0.85 & 1.62 & 1.17 & 0.34 & -2.1 & $36: 36$ \\
\hline $\mathrm{Ca} a^{*}---$ & 2.2 & 1.93 & 1.04 & 0.59 & -8.2 & $36: 36$ \\
\hline $\mathrm{Co}_{0}---$ & 5.5 & 1.49 & 1.16 & 2.6 & -12 & $36: 36$ \\
\hline $\mathrm{Cu}_{\mathrm{u}}-\ldots$ & 15 & 1.70 & 1.38 & 6.5 & -35 & $36: 36$ \\
\hline $\mathrm{Fe}^{*}-\cdots$ & 1.5 & 1.36 & 1.07 & 0.82 & $-\quad 2.7$ & $36: 36$ \\
\hline Ga---- & 15 & 1.32 & 1.17 & 9.5 & -24 & $36: 36$ \\
\hline $\mathrm{Hg}----$ & 0.020 & 1.45 & 1.28 & 0.011 & $1-\quad 0.035$ & $35: 36$ \\
\hline Li-- - & 15 & 1.49 & 1.08 & 6.9 & -33 & $36: 36$ \\
\hline$M g *---$ & 0.63 & 1.54 & 1.05 & 0.27 & $-\quad 1.5$ & $36: 36$ \\
\hline Na*-- & 1.3 & 1.26 & 1.03 & 0.8 & -2.1 & $36: 36$ \\
\hline $\mathrm{S}_{\mathrm{c}-\cdots}$ & 5.3 & 1.47 & 1.23 & 2.8 & -10 & $34: 36$ \\
\hline $\mathrm{Si} *---$ & 31 & 1.07 & 1.03 & 28 & -35 & $36: 36$ \\
\hline $\mathrm{Sr}=--$ & 340 & 1.42 & 1.13 & 180 & -660 & $36: 36$ \\
\hline Th----- & 12 & 1.43 & 1.10 & 6.0 & -24 & $36: 36$ \\
\hline Ti*---- & 0.22 & 1.22 & 1.07 & 0.15 & -0.32 & $36: 36$ \\
\hline $\mathrm{Zn}_{n}--\infty$ & 43 & 1.31 & 1.08 & 26 & -72 & $36: 36$ \\
\hline
\end{tabular}

${ }^{1}$ Expected 95-percent range.

TABLE 6.-Statistical summary for the element having regional variation in soils that overlie the three major geologic units in the Bighorn Basin

[Detection ratio, number of samples in which the element was found in measurable concentrations relative to the number of samples analyzed; *, elements measured in percent; other elements measured in parts per million]

\begin{tabular}{lccccc}
\hline Element & $\begin{array}{c}\text { Geometric } \\
\text { mean }\end{array}$ & $\begin{array}{c}\text { Geometric } \\
\text { deviation }\end{array}$ & $\begin{array}{c}\text { Geometric } \\
\text { error }\end{array}$ & $\begin{array}{c}\text { Baseline } \\
\text { value }\end{array}$ & $\begin{array}{c}\text { Detection } \\
\text { ratio }\end{array}$ \\
\hline Willwood Formation \\
\hline
\end{tabular}

\begin{tabular}{llllll}
\hline \multicolumn{6}{c}{ Fort Union Formation } \\
\hline Zn--- & 66 & 1.36 & 1.11 & $37-118$ & $12: 12$
\end{tabular}

\begin{tabular}{llllll}
\hline \multicolumn{5}{c}{ Quaternary deposits } \\
\hline Zn---- & 55 & 1.26 & 1.11 & $36-83$ & $12: 12$
\end{tabular}

${ }^{1}$ Expected $95-$ percent range.

sorption was used for the determination of $\mathrm{Rb}$ concentration.

\section{BASELINE VALUES}

A total of 31 elements in soils from the Bighorn Basin (table 2) and 19 elements in soils from the Wind River Basin (table 3) do not exhibit statistically significant
TABLE 7.-Statistical summary for elements having regional variation in soils that overlie the three major geologic units in the Wind River Basin

[Detection ratio, number of samples in which the element was found in measurable concentrations relative to the number of samples analyzed; *, elements measured in percent; other elements measured in parts per million]

\begin{tabular}{|c|c|c|c|c|c|}
\hline Element & $\begin{array}{l}\text { Geometric } \\
\text { mean }\end{array}$ & $\begin{array}{l}\text { Geometric } \\
\text { deviation }\end{array}$ & $\begin{array}{l}\text { Geometric } \\
\text { error }\end{array}$ & $\begin{array}{l}\text { Baseline } \\
\text { value }^{1}\end{array}$ & $\begin{array}{l}\text { Detection } \\
\text { rat io }\end{array}$ \\
\hline \multicolumn{6}{|c|}{ Moonstone and Arikaree Formations } \\
\hline $\mathrm{A} 1$ *--_-- & 4.4 & 1.18 & 1.08 & $3.3-5.9$ & $12: 12$ \\
\hline Cr----- & 27 & 1.45 & 1.11 & $13-55$ & $12: 12$ \\
\hline K*---- & 2.1 & 1.13 & 1.06 & $1.7-2.6$ & $12: 12$ \\
\hline Mo---.-- & 3.7 & 1.64 & 1.23 & $1.5-9.1$ & $11: 12$ \\
\hline Mn---.-- & 270 & 1.50 & 1.15 & $130-580$ & $12: 12$ \\
\hline Ni----- & 12 & 1.56 & 1.16 & $5-28$ & $12: 12$ \\
\hline U------ & 2.6 & 1.15 & 1.05 & $2.0-\quad 3.4$ & $12: 12$ \\
\hline V------ & 43 & 1.44 & 1.11 & $21-86$ & $12: 12$ \\
\hline \multicolumn{6}{|c|}{ Wind River and Indian Meadows Formations } \\
\hline $\mathrm{Al} *----$ & 5.0 & 1.16 & 1.08 & $3.9-\quad 6.4$ & $12: 12$ \\
\hline Cr----- & 52 & 1.36 & 1.11 & $29-93$ & $12: 12$ \\
\hline K*----- & 2.0 & 1.09 & 1.06 & $1.8-2.3$ & $12: 12$ \\
\hline Mo----- & 5.0 & 1.43 & 1.23 & $2.8-9.0$ & $12: 12$ \\
\hline Mn------ & 320 & 1.29 & 1.15 & $210-490$ & $12: 12$ \\
\hline Ni----- & 21 & 1.39 & 1.16 & $12-38$ & $12: 12$ \\
\hline U------ & 2.9 & 1.27 & 1.05 & $1.8-4.6$ & $12: 12$ \\
\hline v---.-- & 48 & 1.22 & 1.11 & $34-67$ & $12: 12$ \\
\hline \multicolumn{6}{|c|}{ Quaternary deposits } \\
\hline$A 1 *---$ & 5.5 & 1.17 & 1.08 & $4.2-7.2$ & $12: 12$ \\
\hline Cr---- & 61 & 1.24 & 1.11 & $42-89$ & $12: 12$ \\
\hline K*----- & 1.9 & 1.12 & 1.06 & $1.6-2.3$ & $12: 12$ \\
\hline Mo----- & 5.8 & 1.43 & 1.23 & $3.2-10.0$ & $12: 12$ \\
\hline Mn----- & 420 & 1.32 & 1.15 & $260-680$ & $12: 12$ \\
\hline Ni----- & 23 & 1.25 & 1.16 & $16-32$ & $12: 12$ \\
\hline U------ & 2.8 & 1.14 & 1.05 & $2.2-3.6$ & $12: 12$ \\
\hline v------ & 53 & 1.26 & 1.11 & $35-80$ & $12: 12$ \\
\hline
\end{tabular}

${ }^{I}$ Expected 95 -percent range.

(0.05 probability level) variability between geologic units and do not exhibit excessive analytical error. Thus, a single baseline value is the optimum estimate to describe the total concentrations of these elements in soils from each of these basins (tables 4 and 5). The results of analysis of variance (tables 2 and 3 ) suggest that the composition of soil samples taken from within different geologic units within a basin are expected to vary little more than the composition of soil samples taken at distances of $5 \mathrm{~km}$ or less apart. The baseline value is defined by Tidball and Ebens (1976) as the expected 95-percent range in concentration in samples of soils in these basins. The expected range is estimated from the residual variation after analytical error has been removed. This residual variation is the natural chemical variation measured between samples and excludes variation due to sample preparation and analysis. 
Rocks of Paleocene age in the Bighorn Basin consist of thin-bedded, light-colored sandstone and conglomerate with drab to olive-brown shale and some red shale in the upper part (Andrews and others, 1947). The rocks of Eocene age in the Wind River Basin are made up of varicolored claystone and siltstone interbedded with white to gray, fine- to medium-grained arkosic sandstone (Keefer, 1965); about half the soils sampled on the Wind River Formation lay on a drab-colored sandstone and shale sequence and the other half, on varicolored mudstone. In the Bighorn Basin, the rocks of Eocene age are typically a variegated shale with abundant beds of white and yellow sandstone composed of unsorted grains whose mineralogy represents crystalline rather than sedimentary rocks as source material (Van Houten, 1944). The Miocene and Pliocene rocks in the Wind River Basin consist of medium- to coarsegrained, gray to buff, massive to coarsely crossbedded sandstone with common limestone beds, algal reefs, and pumicite beds, and also consist of stratified gray arkosic conglomerate containing boulders of granite and Paleozoic rock (Love, 1970). These rocks of Miocene and Pliocene age are different in composition from strata of Eocene age in the Wind River Basin. The deposits of Quaternary age are highly variable; the soils at the sampling localities on the western end of the barbell in the Wind River Basin are mostly developed in finegrained alluvium (Thompson, 1954) in the nearly undrained part of the Wind River Basin in which Ocean Lake was formed when irrigation began. Two of the localities at the southeastern end of the same barbell are on low terrace deposits along the Wind River north of the city of Riverton, and four are on erosional remnants of coarse-grained, bouldery, high-terrace deposits (Thompson, 1954). On Quaternary deposits in the Bighorn Basin, three sampling localities are on the Powell terrace 50 to $80 \mathrm{~m}$ above present stream level; five are on high, dissected gravelly pediment surfaces older than the Powell terrace; and four are on gravelly pediment surfaces younger than the Powell terrace (Andrews and others, 1947).

The rock types described for the various geologic units differ from one another in ways that suggest they should differ also in chemical composition. The nonsignificant variability between the soils on the geologic units for most elements in both basins suggests that the soils on strata of different ages are not chemically distinct from one another. This implies that either the soils are not genetically related to the rock units which they overlie or, if the soils represent the compositions of the rock units, that the rock units are not chemically distinct from one another. Possibly, the soils are not genetically related to the geologic units because soil composition reflects surficial geology and geomorphology of
Holocene age rather than rock-stratigraphic units of Tertiary age. However, for the Wind River Basin, several elements exhibit significant variability between soils on the various map units.

Zinc is the only element that exhibits a significant variability in soil between map units from the Bighorn Basin (table 2). The soils sampled on the Fort Union Formation had the highest average $\mathrm{Zn}$ concentration, and those on the Willwood Formation and deposits of Quaternary age were about equal. However, in the Wind River Basin, eight elements ( $\mathrm{Al}, \mathrm{Cr}, \mathrm{K}, \mathrm{Mn}, \mathrm{Mo}, \mathrm{Ni}, \mathrm{U}$, and $\mathrm{V}$ ) exhibit variability between geologic units that is significant at the 0.05 probability level; Rb was eliminated because of excessive analytical error. All these elements, except $K$, were highest in average concentration in soils on deposits of Quaternary age and lowest in average concentration on those soils developed in the Miocene Moonstone and Pliocene Arikaree Formations. For K, the trend was reversed. Concentrations of these elements are best described by individual estimates of a baseline for each mapping unit, because the differences between mapping units are greater than the differences between samples within the mapping units. Statistical summaries and baseline values for these elements are given in tables 6 and 7.

Summary data on the average composition of soils of the Bighorn and Wind River Basins, of soils and surficial materials of the Powder River Basin, and of surficial materials of the Western United States are presented in table 8 . The data show that, for most elements, the average composition of the soil differs little between the Bighorn Basin, the Wind River Basin, the Powder River Basin, and the Western United States. Concentrations of $\mathrm{Na}$ in soil in the Wind River Basin; $\mathrm{B}, \mathrm{C}$, and $\mathrm{Ca}$ in the Bighorn Basin; and $\mathrm{Ba}, \mathrm{Be}, \mathrm{Mo}$, and $\mathrm{Sr}$ in both basins are 50 to 100 percent higher than in soils in either the Powder River Basin or the Western United States. $\mathrm{Li}$ is the only element in the Wind River and Bighorn Basins that is about 50 percent lower in concentration than in either the Powder River Basin or the Western United States. However, concentrations that differ by a factor of one to two are generally within a 95-percent expected range and should not be considered as anomalous values that warrant special consideration.

\section{MAPPING REQUIREMENTS}

This geochemical survey is preliminary in character; it is conducted mainly to measure chemical variability and to estimate the magnitude of the sampling effort that will be required to assess the present, natural geochemical status of the soils in each basin. Data from the analysis of variance are useful for estimating the 
TABLE 8.-Average concentrations (geometric means) of elements in soils and surficial materials in the Bighorn, Wind River, and Powder River Basins and in the Western United States

[All elements in Bighorn and Wind River Basins are included regardless of the magnitude of analytical error; *, element measured in percent; other elements measured in parts per million; ---, no data available]

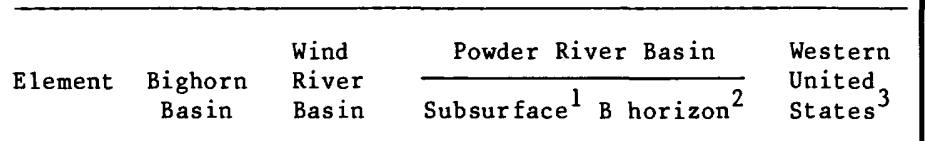

\begin{tabular}{|c|c|c|c|c|c|}
\hline $\mathrm{A} 1 *----$ & 4.0 & 5.0 & -- & 5.6 & 5.4 \\
\hline As- - & 4.7 & 3.6 & $-\infty$ & $-\infty$ & 6.1 \\
\hline$B--\cdots$ & 50 & 28 & 26 & 30 & 22 \\
\hline $\mathrm{Ba}-\infty$ & 1300 & 1500 & 720 & 660 & 560 \\
\hline $\mathrm{Be}-----$ & 2.0 & 2.4 & .99 & $-\infty$ & .6 \\
\hline C-D- & 1.5 & .85 & -- & .88 & -- \\
\hline $\mathrm{Ca}^{*}-\cdots-$ & 3.0 & 2.2 & -- & .87 & 1.8 \\
\hline $\mathrm{Ce}----$ & 57 & 54 & -- & --- & 74 \\
\hline Co----- & 6.3 & 5.5 & 6.3 & 7.6 & 8 \\
\hline $\mathrm{Cr}=---$ & 59 & 52 & 49 & 46 & 88 \\
\hline $\mathrm{Cu}=---$ & 20 & 15 & 16 & 17 & 21 \\
\hline $\mathrm{Fe}^{*----}$ & 1.8 & 1.5 & -- & 2.2 & 2.0 \\
\hline $\mathrm{Ga}--\cdots--$ & 11 & 15 & 13 & -- & 18 \\
\hline $\mathrm{Ge}-\cdots$ & .87 & .88 & -- & --- & -- \\
\hline $\mathrm{Hg}-----$ & .25 & .020 & .023 & .022 & .055 \\
\hline
\end{tabular}

\begin{tabular}{|c|c|c|c|c|c|}
\hline $\mathrm{Hg}---\infty$ & .25 & .020 & .023 & .022 & .055 \\
\hline K*----- & 1.5 & 2.0 & -- & ${ }^{4} 2.0$ & 1.7 \\
\hline La-- - & 36 & 33 & 28 & -- & 35 \\
\hline Li----- & 18 & 15 & 24 & ${ }^{5} 27$ & 23 \\
\hline Mg*---- & .86 & .63 & -- & .67 & .78 \\
\hline Mn----- & 400 & 320 & 230 & 270 & 389 \\
\hline Mo----- & 4.8 & 5.0 & $<3$ & -- & -- \\
\hline $\mathrm{Na} a_{----}$ & .53 & 1.3 & -- & 4.45 & 1.0 \\
\hline $\mathrm{Nb}-----$ & 8.9 & 6.9 & 6.2 & -- & 11 \\
\hline $\mathrm{Ni}=----$ & 22 & 21 & 15 & 17 & 16 \\
\hline $\mathrm{Pb}=---$ & 8.6 & 13 & 17 & 18 & 18 \\
\hline $\mathrm{Rb}-----$ & 55 & 63 & -- & -- & --- \\
\hline $\mathrm{Sb}-----$ & .16 & .23 & $-\cdots$ & -- & --- \\
\hline Sc----- & 5.9 & 5.3 & 7.8 & 8.6 & 9 \\
\hline Si*- - - & 32 & 31 & -- & $5_{34}$ & -- \\
\hline Sn----- & .71 & .87 & --- & --- & -- \\
\hline Sr----- & 230 & 340 & 160 & 160 & 210 \\
\hline Th----- & 8.5 & 12 & 9.6 & -- & -- \\
\hline Ti*---- & .26 & .22 & -- & 5.29 & .21 \\
\hline U------ & 2.7 & 2.9 & 3.0 & --- & -- \\
\hline V---D- & 68 & 48 & 87 & 78 & 66 \\
\hline $\mathrm{Y}------$ & 20 & 18 & 17 & -- & .25 \\
\hline Yb----- & 2.7 & 2.6 & 1.8 & --- & 3 \\
\hline Zn----- & 57 & 43 & 61 & ${ }^{5} 66$ & 51 \\
\hline $\mathrm{Zr}----$ & 320 & 230 & 140 & 200 & 170 \\
\hline
\end{tabular}

${ }_{2}^{1}$ Connor, Keith, and Anderson (1976).

2 Tidbali and Ebens (1976).

3 Surficial material, from Shacklette and others (1971a, b, 1973, 1974).

${ }_{5}^{4}$ Arithmetic mean of four geometric means.

${ }^{5}$ Arithmet ic mean.

number of samples that would be required within an area of specified size to prepare a reliable map of total element concentration.

Sampling cells $10 \mathrm{~km}$ on a side were arbitrarily chosen to illustrate the concepts used in interpreting the analysis of variance and applying it to the preparation

of maps of regional variation. Such variation may easily be mapped as differences between cell averages, if an adequate number of random samples are taken within each cell to produce a stable average. The methods for estimating the minimum number of random samples $\left(n_{r}\right)$ required in each cell, based on the concept of a variance ratio $(v)$, were developed by Miesch (1976). The variance ratio is a ratio of the variance measured between increments of distance (in this case $10 \mathrm{~km}$ ) to the variance measured within increments of distance. The minimum number of random samples that need to be collected in each $10-\mathrm{km}$ cell is determined from the following equation:

$$
F=1+n_{r} v
$$

where $n_{r}$ is adjusted so that the sum, $\left(1+n_{r} v\right)$, exceeds the critical $F$-statistic $(F)$ at the 80 percent confidence interval with 1 and $2 n_{r}-2$ degrees of freedom.

Table 9 summarizes the number of mappable elements in each basin for increasing $n_{r}$ values. Maps showing regional distribution of $\mathrm{C}$ and $\mathrm{Na}$ concentration in soil in the Bighorn Basin and $\mathrm{Cr}$ in the Wind River Basin would require a minimum sampling intensity of two random samples per $10-\mathrm{km}$ cell to describe more than half of the natural variation. At the other extreme, it would not be feasible to attempt a mapping program based on $10-\mathrm{km}$ cells for several elements in each basin (elements labeled "n.d." in table 9). For these

TABLE 9.-Minimum number of random samples needed $\left(\mathbf{n}_{\mathbf{r}}\right)$ in a $10-\mathrm{km}$ square to map total element concentrations in soils of the Bighorn and Wind River Basins at the 80 percent confidence level

[--, no element can be mapped in a basin using this $n$, value; n.d., not determined because $n$ is infinitely large]

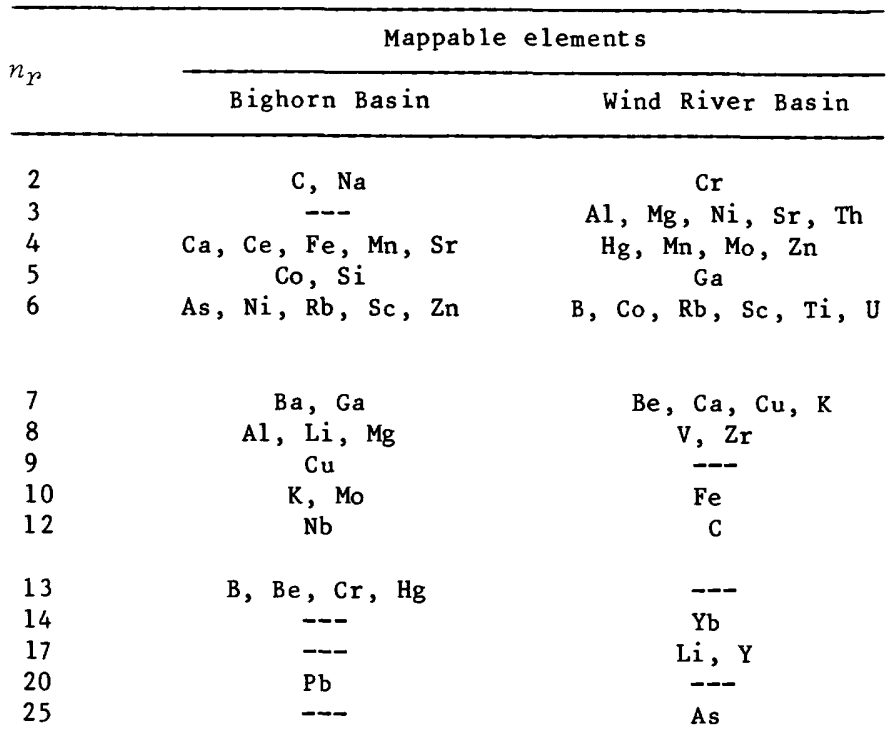

Ge, La, Sn, Th, Ti, $\mathrm{U}, \mathrm{V}, \mathrm{Y}, \mathrm{Yb}, \mathrm{Zr}$
$\mathrm{Ba}, \mathrm{Ce}, \mathrm{Ge}, \mathrm{La}, \mathrm{Na}$ $\mathrm{Nb}, \mathrm{Pb}, \mathrm{Si}, \mathrm{Sn}$ 
elements, variation estimated at distances of $10 \mathrm{~km}$ or greater was very small or nonexistent, so a minimum sampling intensity could not be calculated. The sampling intensity necessary to map the regional distribution of single elements differs between the Bighorn and Wind River Basins. For example, if there is interest in mapping the regional distribution of Mo in the Bighorn Basin, it would require a minimum of 10 random samples per $10-\mathrm{km}$ cell. To map the regional distribution of Mo in the Wind River Basin would require a minimum of four random samples per cell. The geographic variability of element concentration is unique for any single element in the sampling area.

The previous paragraphs have illustrated the methods for determining minimum sampling intensity for mapping variation in element concentration between $10-\mathrm{km}$ cells. Similar tables of minimum sampling intensities can be constructed for each element in each basin for 5 - or $1-\mathrm{km}$ cells by using the analysis-ofvariance data in tables 2 or 3 to compute the variance ratios and by using Equation 1 to compute $n_{r}$ values. The analysis-of-variance data can also be used to estimate the portion of the total variation explained by the size of the geographic unit selected for mapping regional distribution. The proportion of the total variation explained for mapping at a $10-\mathrm{km}$ cell size is determined by summing the analysis-of-variance values for "Between Map Units" and "10-25 km" (tables 2 or 3). For example, mapping Mo at a $10-\mathrm{km}$ interval with a sampling intensity of 10 samples per cell in the Bighorn Basin and 4 samples per cell in the Wind River Basin would describe only about 8 percent of the natural variation of this element in the Bighorn Basin (table 2) and only about 22 percent of the natural variation in the Wind River Basin (table 3). To describe more than half of the natural variation of an element concentration, add together the percent of total variance at each level of the sampling design, starting with the "Between Map Unit" level (tables 2 or 3 ), until a value of 50 percent is exceeded. To describe more than half of the natural variation of Mo, it would be necessary to sample at a $1-\mathrm{km}$ interval in the Bighorn Basin and at an interval of $<1$ $\mathrm{km}$ in the Wind River Basin. At either of these intervals, the sampling load and costs would be very high.

Because of the dominant local variation for most elements, the baseline value is more practical than a map of regional variation. For most elements, maps prepared at an interval requiring a reasonable sample load would explain a very small portion of the total natural variation, whereas, at the other extreme, maps that explain a reasonable portion of the total natural variation would require such a large sample load as to be impractical at present.

\section{CONCLUSIONS}

This reconnaissance study of spatial variation in total concentration of elements in soils in the Bighorn and Wind River Basins suggests the following:

1. Geographic variation in total concentration of elements in soil occurs mainly at distance intervals of less than $5 \mathrm{~km}$.

2. Because of the large local variation, individual measurements of total element concentration in soil cannot be extrapolated over great distances.

3. The summary data for a group of samples, however, expressed as a baseline value, may be extrapolated over great distances (geologic units or whole basins) depending on the magnitude of the regional variation.

4. The lack of significant variation between geologic units for most elements suggests that soils mask the presumed variation between rock differences that make up the mapping units and possibly indicates that the soil materials are not genetically related to the geologic mapping units. This lack of significant relations between soil composition and geologic units seems reasonable, because soil composition probably reflects differences in surficial geology and geomorphology of Holocene age rather than rockstratigraphic units of Tertiary age.

5. The average concentration for most elements in soil is not greatly different between the Bighorn, Wind River, and Powder River basins or the Western United States. The geometric means for $\mathrm{Ba}, \mathrm{Be}, \mathrm{Mo}$, and $\mathrm{Sr}$ in soil, however, in both the Bighorn and Wind River Basins are 50 to 100 percent greater than in the Powder River Basin or the Western United States. Concentrations of $\mathrm{Na}$ in soil in the Wind River Basin and $\mathrm{B}, \mathrm{C}$, and $\mathrm{Ca}$ in soil in the Bighorn Basin are also slightly higher than in the other areas. Lithium in soil in the Bighorn and Wind River Basins has an average concentration that is about half that in the Powder River Basin or the Western United States; however, these values generally lie within an expected 95-percent range in concentration and should not be considered anomalous values.

6. The analysis of variance indicates that it is possible to map regional variation in element concentration in soil as differences among $10-\mathrm{km}$ cell averages for $\mathrm{C}$ and $\mathrm{Na}$ in the Bighorn Basin and for $\mathrm{Cr}$ in the Wind River Basin; with only two random samples per cell, a large portion of the natural variation would be described. At the other extreme, it is not feasible to even attempt to map regional variation for several elements, because analysis of variance indicates that little or no variation is expected to exist at $10-\mathrm{km}$ or greater distances. Therefore, for most elements in 
soil in both basins, a mapping program designed to describe more than half of the natural variation in element concentration is impractical.

\section{REFERENCES CITED}

Andrews, D. A., Pierce, W. G., and Eargle, D. H., 1947, Geologic map of the Bighorn Basin, Wyoming and Montana, showing terrace deposits and physiographic features: U. S. Geological Survey Oil and Gas Investigations Preliminary Map 71, scale 1:125,000.

Connor, J. J., Keith, J. R., and Anderson, B. M., 1976, Trace-metal variation in soils and sagebrush in the Powder River Basin, Wyoming and Montana: U.S. Geological Survey Journal of Research, v. 4, no. 1 , p. 49-59.

Keefer, W. R., 1965, Stratigraphy and geologic history of the uppermost Cretaceous, Paleocene, and lower Eocene rocks in the Wind River Basin, Wyoming: U.S. Geological Survey Professional Paper 495-A, $77 \mathrm{p}$.

Love, J. D., 1970, Cenozoic geology of the Granite Mountain area, central Wyoming: U.S. Geological Survey Professional Paper 495-C, $154 \mathrm{p}$.

Miesch, A. T., 1976, Geochemical survey of Missouri-methods of sampling, laboratory analysis, and statistical reduction of data: U.S. Geological Survey Professional Paper 954-A, 39 p.

Shacklette, H. T., Hamilton, J. C., Boerngen, J. G., and Bowles, J. M., 1971, Elemental composition of surficial materials in the conterminous United States: U.S. Geological Survey Professional Paper 574-D, $71 \mathrm{p}$

Shacklette, H. T., Boerngen, J. G., and Turner, R. L., 1971, Mercury in the environment-surficial materials of the conterminous United States: U.S. Geological Survey Circular 644, 5 p.

Shacklette, H. T., Boerngen, J. G., Cahill, J. P., and Rahill, R. L., 1973, Lithium in surficial materials of the conterminous United States and partial data on cadmium: U.S. Geological Survey Circular $673,8 \mathrm{p}$.

Shacklette, H. T., Boerngen, J. G., and Keith, J. R., 1974, Selenium, fluorine, and arsenic in surficial materials of the conterminous United States: U.S. Geological Survey Circular 692, 14 p.

Thompson, R. M., and White, V. L., 1954, Geology of the Riverton area, central Wyoming: U.S. Geological Survey Oil and Gas Investigations Map OM-127, scale 1:63,360.

Tidball, R. R., and Ebens, R. J., 1976, Regional geochemical baselines in soils of the Powder River Basin, Montana-Wyoming, in Laudon, R. B., ed., Geology and energy resources of the Powder River: Wyoming Geological Association Guidebook, Twentyeighth Annual Field Conference, Casper, Wyoming, September 1976 , p. $299-310$.

U.S. Geological Survey, 1975, Geochemical survey of the Western Coal Regions, second annual progress report, July 1975: U.S. Geological Survey Open-File Report 75-436, $132 \mathrm{p}$.

Van Houten, F. B., 1944, Stratigraphy of the Willwood and Tatman formations in northwestern Wyoming: Geological Society of America Bulletin, v. 55, no.2, p. 165-210.

VanTrump, George, Jr., and Miesch, A. T., 1977, The U.S. Geological Survey RASS-STATPAC system for management and statistical reduction of geochemical data: Computers and Geoscience, v. 3, p. 475-488.

Whitcomb, H. A., and Lowry, M. E., 1968, Ground-water resources and geology of the Wind River Basin area, central Wyoming: U.S. Geological Survey Hydrologic Investigations Atlas HA-270, scale 1:250,000. 